\title{
Morphology and movements of nearshore sediments in a non-tidal environment, Køge Bugt,
} Denmark

\author{
NIELS NIELSEN and JØRGEN NIELSEN
}

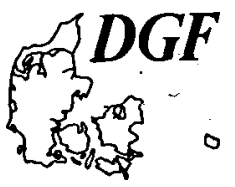

\begin{abstract}
Nielsen, N. \& Nielsen, J.: Morphology and movements of nearshore sediments in a non-tidal environment, Køge Bugt, Denmark. Bull. geol. Soc. Denmark, vol. 27, pp. 15-45. Copenhagen, October 1st 1978. https://doi.org/10.37570/bgsd-1978-27-03
\end{abstract}

\begin{abstract}
On a non-tidal, medium- to fine-grained sandy coast, the morphology and material budget in the littoral zone - primarily on the nearshore terrace and the shoreface - have been analysed on the basis of 65 detailed maps surveyed in a permanent grid for a period of two months. Simultaneously, records were made of wind, water, and waves. The map drawings and the calculations of variations in sediment volumes were made by EDP.

The investigations showed that the nearshore bar might be built up during high as well as low waterlevels, initiated either by a small breakpoint bar or a swash bar. The observed nearshore bar moved landward up to $30 \mathrm{~cm}$ per hour during periods with onshore winds and during constant water-levels and/ or constant wind speeds.

Analyses of the material budget showed that variations in volume (down to minus $1 \mathrm{~m}$ ) were mainly due to profile adjustments. Especially noteworthy was that, after a gale, the quantities of sediments supplied were larger than those removed from the area during the gale. Furthermore, it was demonstrated that the total quantity of material of the inshore and the beach by and large remained constant in spite of obvious occurrences of nearshore bars migrating towards the coastline during the investigation period. Only an extraordinary gale situation was able to add permanent material to the barrier.
\end{abstract}

N. Nielsen and J. Nielsen, Laboratorium for Geomorfologi, Geografisk Centralinstitut, Haraldsgade 68, 2100 København Ø, Denmark. January 23rd, 1978

On a non-tidal, low-energy coast a detailed knowledge of the nearshore dynamics is necessary to understand the conditions governing the stability of the coastal zone.

In any wave situation the inshore zone will be exposed to transformation of energy the morphological effect of which depends not only on the wave parametres, but also on the actual waterlevel. This means that the littoral zone displays a great variety of bed forms all with the essential quality that they are seldom stable for longer periods. The predominant form is here the nearshore bar - which is easy to identify by its shape and its movement pattern.

The present paper is an attempt to illustrate some of the problems connected with the importance of the nearshore bar for the material budget along the Danish coasts. The basic field work was performed on Jersie Strand, Køge Bugt (fig. 1), where any change in forms occurring within an area of $48 \times 86 \mathrm{~m}$ during the two-month period, from September to November 1971, was registered. Simultaneously, data of wind and water-level were recorded by self-registering instruments (Ott, Schreibpegel, type $\mathrm{X}$ and Lambrecht anemometer, type 1438).

\section{Description of the locality}

The bay of Køge Bugt is located south of Copenhagen and is hydrographically part of the Baltic Sea. The geomorphological appearance of the bay is due to a late advance of the ice from the SE during the Weichsel glaciation. The water depths in the Køge Bugt area are shallow (maximum 20 $\mathrm{m})$ as are also the fetches, except towards the SE. South of the beach Jersie Strand, in the central part of the bay, a shallow extends about $10 \mathrm{~km}$ towards the ESE. The tidal range in this part of the Baltic is less than $10 \mathrm{~cm}$.

Earlier maps show that a barrier was under formation at least in 1860, but not until 1907 was it reproduced as a chain of islets on topographical maps. Development has since then been rapid, and already the topographical map from 1952 shows a continuous barrier system, at least $7 \mathrm{~km}$ long and only broken by two tidal inlets.

On the northern part of the barrier, about 400 $m$ north of a tidal inlet where the marine processes were assumed to work undisturbed by the inlet dynamics, the observation area was set up, (figs $1 \& 2$ ). The width of the barrier is here about $85 \mathrm{~m}$, and it consists of 2 ridges of which 


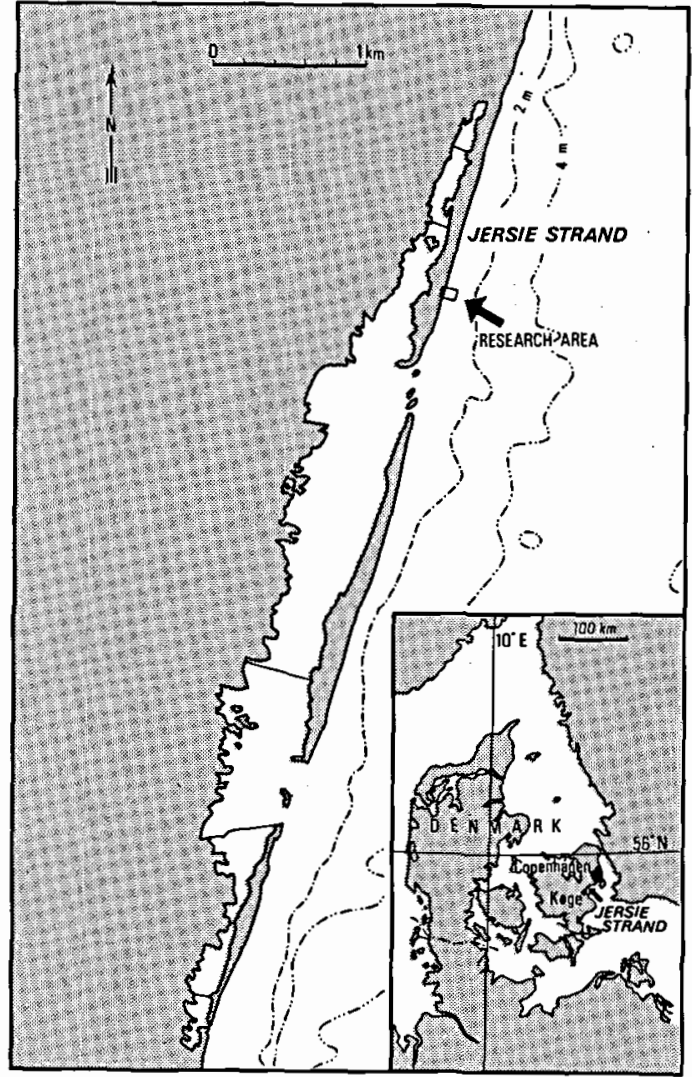

Fig. 1. Map showing the location of the study area in the central part of the bay Køge Bugt.

the oldest one reaches a height of $1.6 \mathrm{~m}$ and the youngest $1.9 \mathrm{~m}$. The morphological border between the marine foreland and the beach (fig. 3) shows in the permanent vegetation, here mainly Elymus arenaria, at a level of about $1.3 \mathrm{~m} \mathrm{DNN}$ (Danish Ordnance Datum), corresponding to the average of the highest water-levels.

Fig. 2. Cross profile of Jersie Strand, Køge Bugt. The profile shows the main elements of the coastal zone: the lagoon, the offshore bar, and the nearshore terrace with the investigated sec-

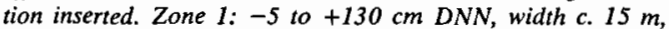
gradient: $5^{\circ}$. Zone $2:-15$ to $-5 \mathrm{~cm} \mathrm{DNN}$, width c. $50 \mathrm{~m}$, gradient: $1^{\circ}$. Zone 3: -80 to $-15 \mathrm{~cm} \mathrm{DNN}$, width c. $25 \mathrm{~m}$, gradient: $2^{\circ}$.
The dynamics and the morphology of the inshore zone have been investigated among others by Schou (1945), King \& Williams (1949), King (1959, 1972), Hayes \& Broothroyd (1969), Hayes (1972), and Davis \& Fox (1972). In these papers there seems to be some uncertainty as to terminology for the easily moved bar type on the nearshore - called the (migrating) nearshore bar by the present authors. The terms ridges and runnels are used by Davis \& Fox (1972) for a tideless environment (Lake Michigan); to some degree, they are thus departing from earlier authors' use of this term, such as King \& Williams (1949) who define ridges and runnels as bar systems on very broad foreshores in typical tidal environments. Unfortunately, King \& Williams, on the other hand, apply the term swash bars for the migrating bars produced in a model basin and which correspond in shape to Davis \& Fox's ridges and runnels; however, these artificial bars differ essentially from the accumulation of sediments occurring: on the foreshore in consequence of the swash/backwash dynamics during swells.

The names of the different coastal zones treated in this work and their location on the coastal profile appear from the term diagram below (fig. 4). It might be reasonable, however, first to comment on the diagram terms as to the subdivisions of the inshore zone, namely breaker zone, shoreface, and nearshore terrace, each covering a specific relief of the sea bottom where different form elements are produced at rising and falling water-levels. If, for example, we imagine the water-level drops considerably in the investigated area because of a temporary wind set-up in the Baltic, the water surface might cut the nearshore zone at the outer nearshore bar shown on the diagram. The foreshore dynamic would move seaward with a subsequent building up of one or more swash bars on the stoss side of the outer nearshore bar. As the swash zone on tideless coasts is identical with the foreshore, the total

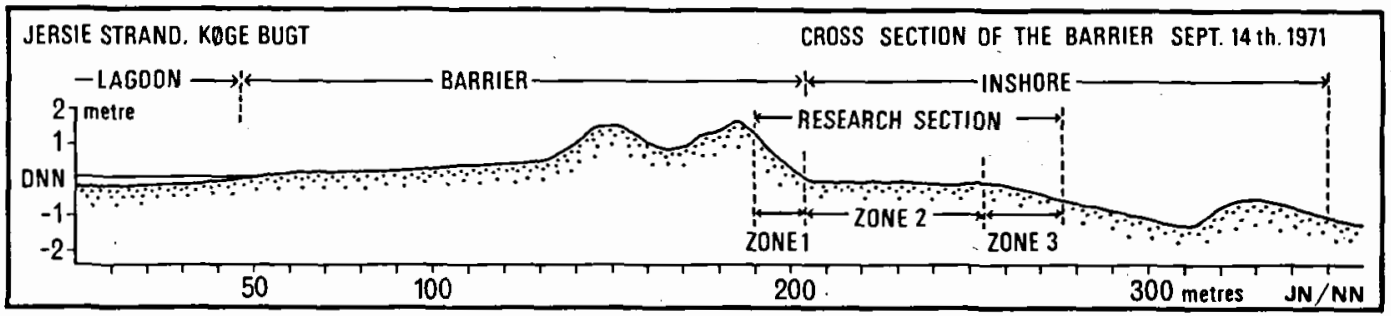




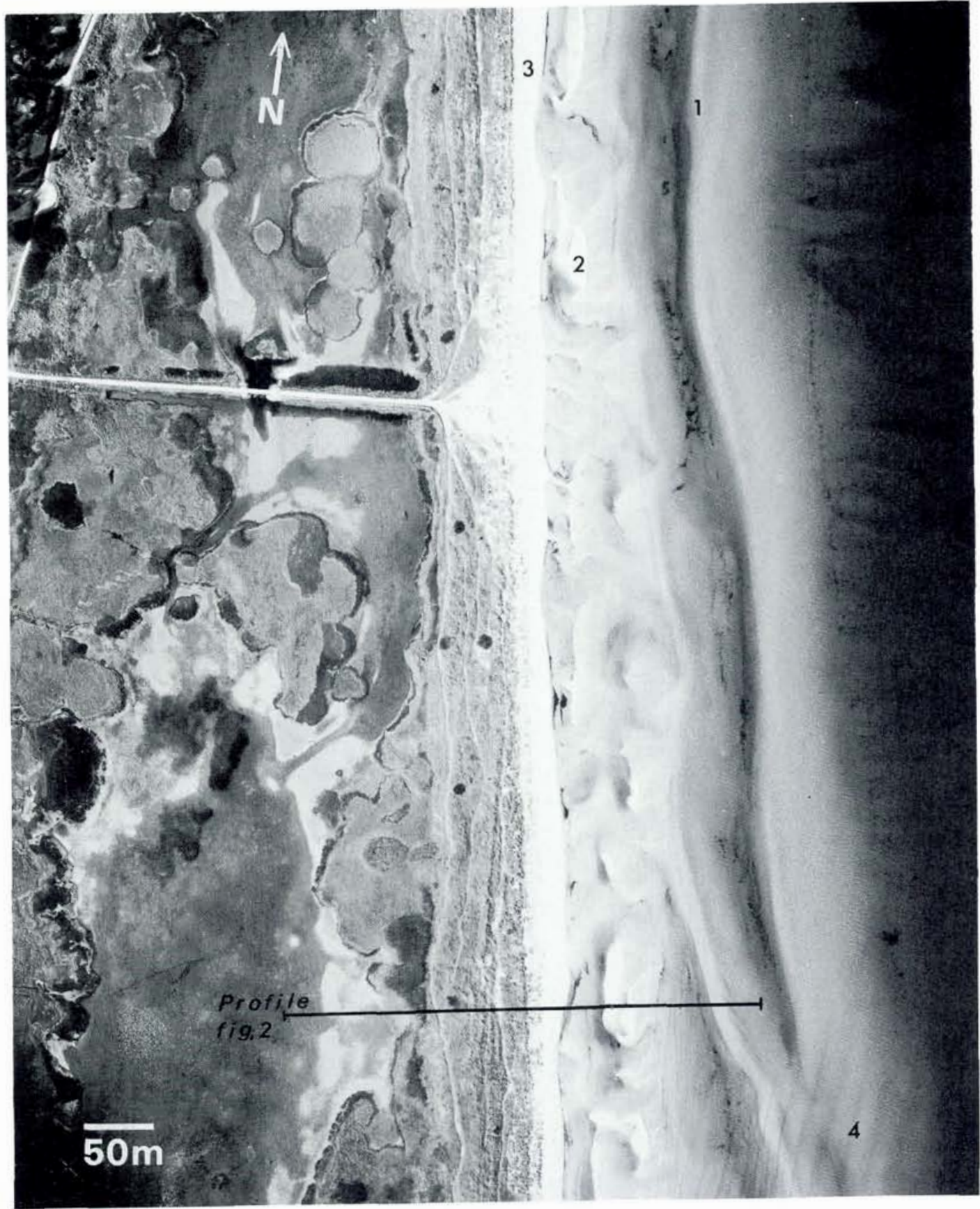

Fig. 3. Part of aerial photograph of Jersie Strand from 21/4 1971. The profile line from fig. 2 is inserted and shows the northern border of the study area. 1. breakpoint bar; 2. nearshore bar; 3. beach and 4. swells. (Air photo: LLO). 

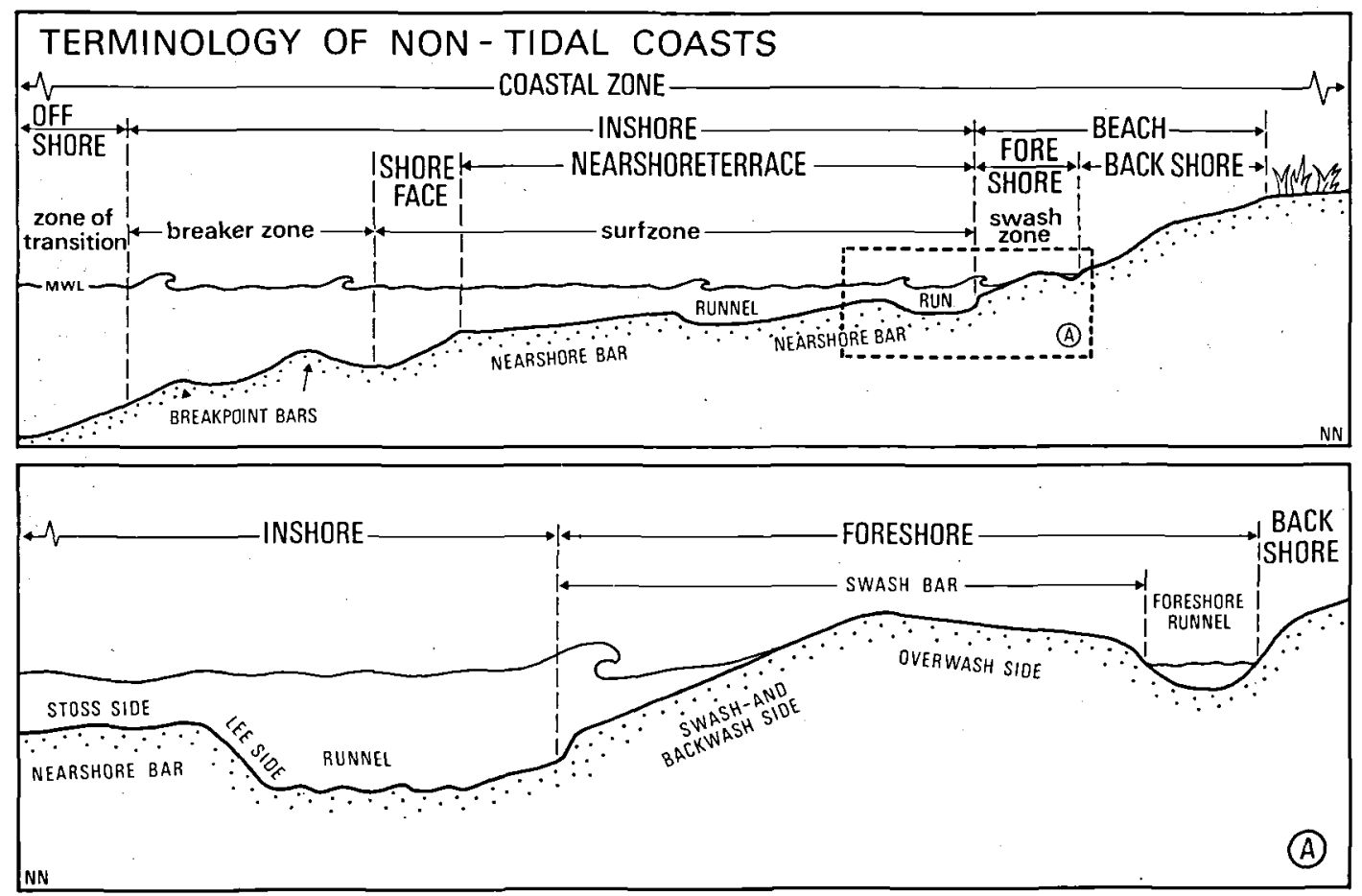

Fig. 4. Terminology of the nearshore environment of a non-tidal coast.

width of the beach would be considerably enlarged during low-water conditions.

The wave zones and the wave characteristics change considerably during low-water periods. These occur mostly with offshore winds. At the same time, however, the nearshore gradient just seaward of the swash zone is steeper than by normal water-levels and this means that the surf zone will be reduced or disappear even under moderate wave activities so that the transition waves dissolve directly into the swash zone.

\section{Collection of data}

In order to make the basic contour maps, the establishment of a rapid, but also accurate measurement method was necessary. Traditional surveying on the basis of tachymetrical measuring would be too timeconsuming both in the field and during the subsequent calculation and working-up of the data. The survey procedure was to fullfil the following conditions: 1) to be operational in any weather situation, 2) each measuring procedure was to be so short that the registered form elements could reasonably be considered a "snapshot" of it, and finally, 3) that the collected amounts of data - which were expected to be large - should not result in more work than could be coped with.

The authors have earlier made sample measurements in grid nets with meshes in isometric triangles in order to avoid interpolation difficulties. As it also gives a good basis for electronic processing, this system was chosen; furthermore the above three points were fulfilled and the calculation and the working up of the single contour maps could be made simultaneously. (The program was set up by Ole Hebin, Geographical Institute, University of Copenhagen).

The grid net was related to an earlier established basis line with points related to DNN. As secondary basis, a line on the backshore was used, located parallel with, and about $0.5 \mathrm{~m}$ off the permanent vegetation border. The point net which covered a morphological unit (nearshore bar and a rip channel) was built up by means of 13 profile lines perpendicular to the basis line and with $4 \mathrm{~m}$-intervals (fig. 9). Each line was furnished with poles (diameter: $22 \mathrm{~mm}$ ) for each 4 


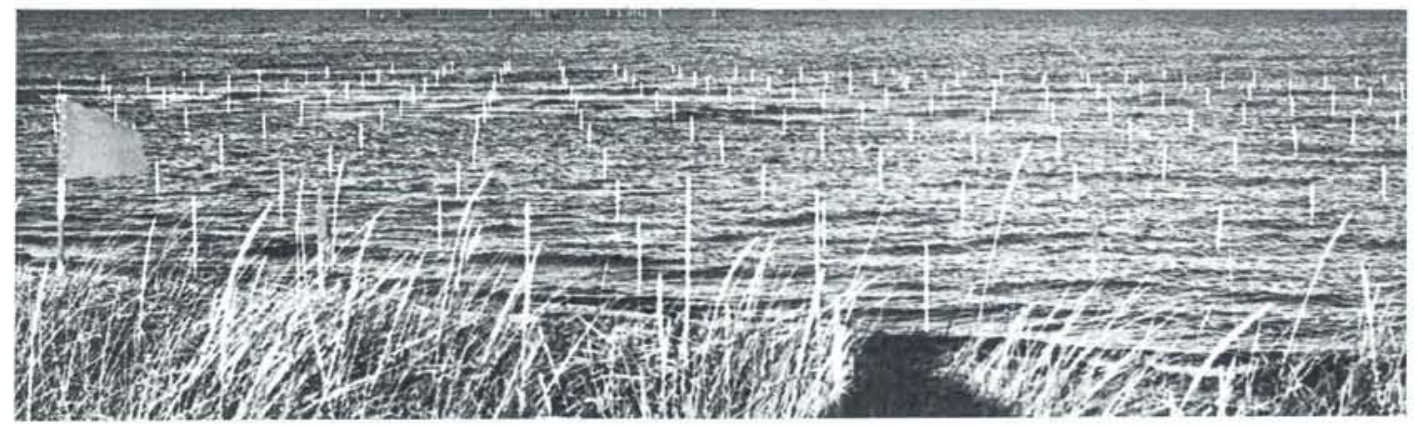

Fig. 5. The measuring net ready for use, seen from the $S W$.

$\mathrm{m}$. The poles were displaced $2 \mathrm{~m}$ in every second line to form an approximately isometrical triangle net with a total of 286 points (fig. 5). The top level of the poles were adjusted to same height above DNN. Routine measurements were made by measuring in each point the distance from the pole top to land and then inform the result over radio to a person on the shore. This procedure

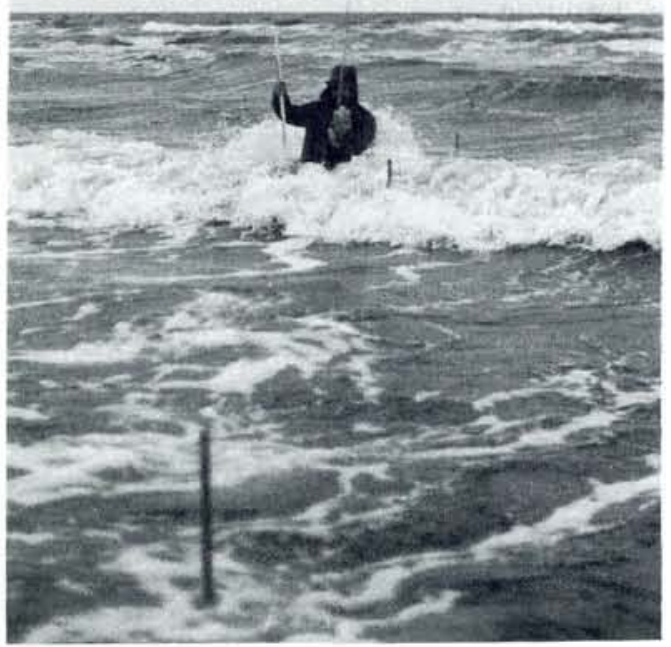

Fig. 6. Measuring in rough weather on 23/9. The permanent pole net makes it possible to take records also under conditions when conventional methods are impossible to use. The single records are transferred to land over the radio. could be performed during all weather conditions in about half an hour with an accuracy of $\pm 2 \mathrm{~mm}$ (fig. 6).

During the period 14/9-11/11 1971 a total of 65 surveys were made. The area was measured at least once a day from $14 / 9$ to $28 / 10$. Furthermore, measurements were made the following days: $30 / 10,1 / 11,4 / 11,7 / 11$ and finally one on $11 / 11$. On days with great wave activity several measurements were made. Thus, two on $16 / 9$, six $23 / 9$, four $27 / 9$, and two $28 / 9$. To avoid misinformation as to the exact location of the nearshore bars, the often sharp border between the surface of the nearshore terrace and the bar front was included in each routine measurement. Furthermore, 13 special measurements were made of the morphological borders existing on the nearshore terrace of rip channels, swash bars, ripple patterns, the border: nearshore/beach etc. The pole net was also applied to investigate the water movements and current conditions in the study area. A balanced float was put out close to a pole and then followed through the net. When passing a pole, coordinates and time were reported over the radio.

The fundamental factors, wind speeds and waterlevels, were measured by means of self-registering instruments. The wind gauge was set up on the barrier itself, whereas the water-level recorder was placed in the harbour of Køge, $6.5 \mathrm{~km}$ from the sample area. To control the actual water-level, a board was set up in the measurement area and mounted with transparant tubes to sub- 
Fig. 7. The mean grain sizes $\left(M_{z}\right)$ and sorting $\left(\delta_{1}\right)$ (Folk \& Ward 1957), shown in relation to the most important morphological borders.

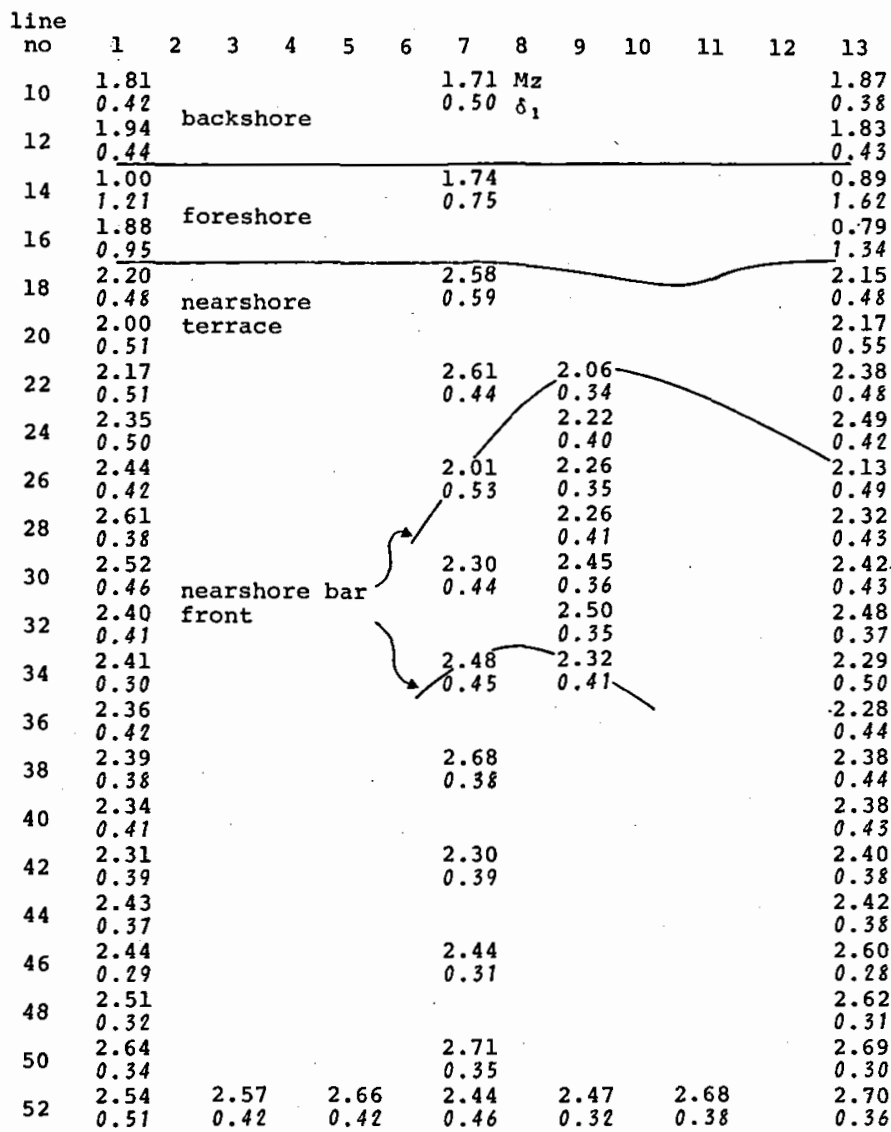

due the water column. Unfortunately, we did not have a recorder at our disposal, so wave heights had to be found by means of the waterlevel board, and wave period and -length had to be measured within the pole net. Compared with the quality of the measurements of form elements, we consider those of waves as a weak link in the present work. To illustrate the sediment conditions of the locality, samplings by a $5 \mathrm{~cm}$ high aluminium cylinder (diameter $4.5 \mathrm{~cm}$ ) were made at each pole in lines 1 and 13 , and at each second pole in line 7 and in crossline 52 (60 samples). Besides this sampling, which gave a general picture of the grain size distribution of the area, a detailed sampling (29 samples) was made in line 9 across a nearshore bar.

\section{Sediments in the study area}

Besides showing a slight difference between the most important morphological zones (backshore, foreshore, nearshore) the statistical parametres demonstrate a homogeneous sediment in the investigation area (fig. 7). A more detailed statistical analysis was therefore only made for the special sampling in line 9 in order to trace possible sorting processes in connection with the formation and migration of the nearshore bar.

Because of the slight variations an F-test was made by pairwise comparison, to investigate whether the sorting of the samples was significantly different. This was only due for combinations of samples from the top of the bar and from the seaward trough; but neighbour samples might mutually originate from the same mother distribution. Where the F-test allowed, at-test was made on the mean grain size. By means of the t-tests' significance levels, it was now possible to separate 3 sediment types. For each group, a weighted average was calculated (fig. 8).

The largest mean grain size was found on the upper part of the flat stoss side of the nearshore bar, the side most exposed to the dynamic forces. 


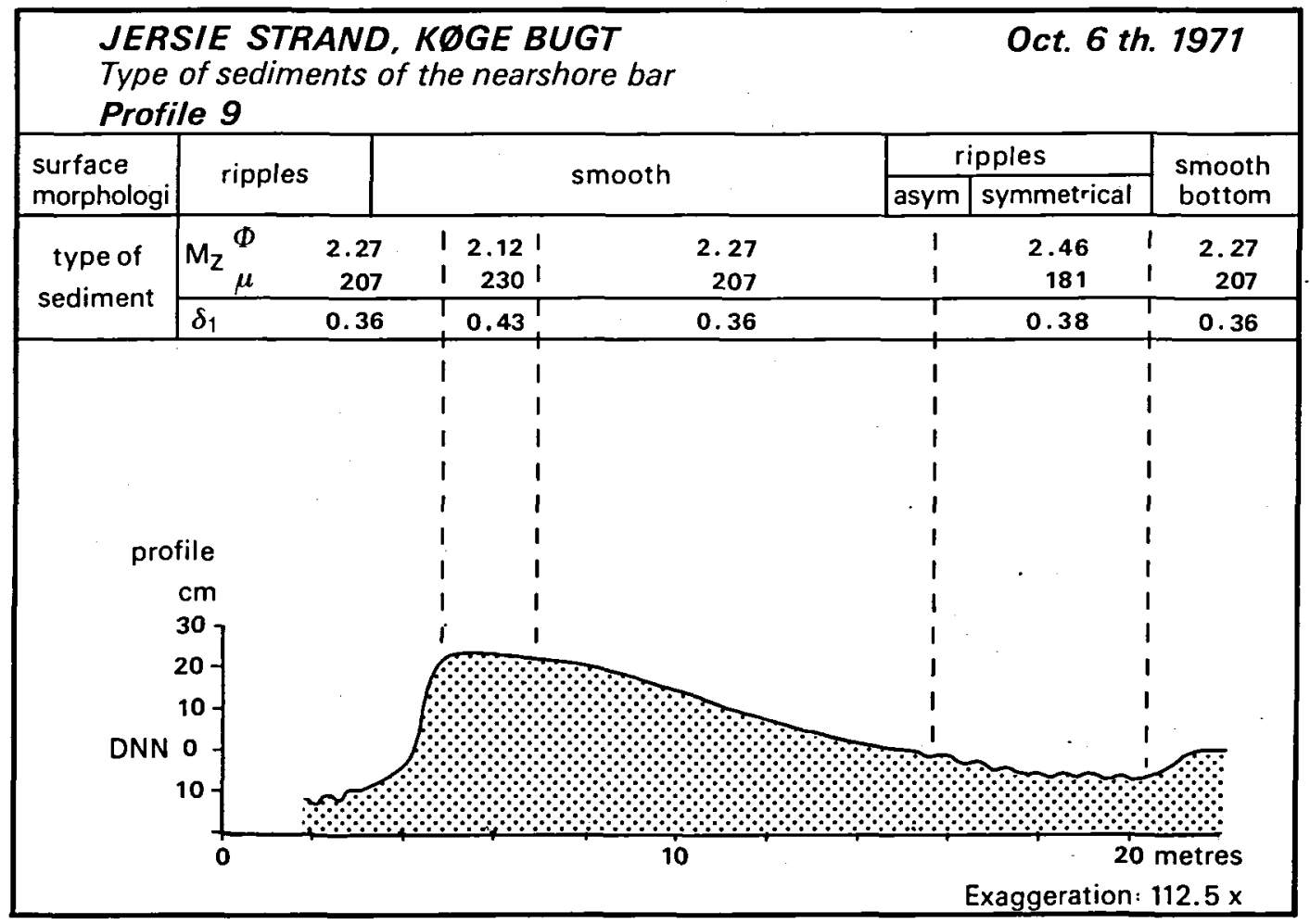

Fig. 8. Relationship between grain size parameters, morphology and bedforms on the nearshore bar in line 9.

During the sampling, variations in the micro morphology of the sea bottom were ascertained. The most coarse-grained sedi- ments were taken at a quite smooth bottom influenced by surf waves, whereas the fine-grained sediments were found in places with ripples formed by the oscillating waves.
The grain size is decreasing both on the leeside and down towards the runnel in front of the next nearshore bar, a pattern which could also be discerned in the general sampling.

\section{Morphological development during the observation period}

The general morphological development in the study area appears from the selected contour maps (figs $9 a-j)$. The nearshore bar migrates onshore at varying speeds, but stagnates before it reaches a complete fusion with the foreshore $(16 / 10$, fig. $9 \mathrm{~g})$, partly because new bars, formed seaward of the old one, absorb a great deal of the wave energy (fig. 11). A characteristic feature in the development of the nearshore bar is that it does not migrate at right angles onshore, but ob- liquely through the study area. During the last part of the investigation period (4/11 to $11 / 11$, figs $9 i-j$ ), the nearshore bar is dissolving just as it leaves the study area.

For more detailed analyses of the morphological development there was constructed besides the contour maps, a map showing the movements of the bar fronts and the swash bars (fig. 12) and a timedistance diagram of the profile lines $1,4,7$, 10 and 13. The T-D diagram makes it possible to correlate the about 20,000 level records from the 65 contour maps and follow the morphological development in connection with wind- and water level observations (figs $10 \mathrm{a}-\mathrm{c}$ ). There were made no statistical levellings of the recorded wind- and water-level data such as Fourier analyses, as suggested by Davis and Fox 1971 and 1972 because the alterations of form on the beach plane terrace take place during specific weather situations and within very short intervals. 


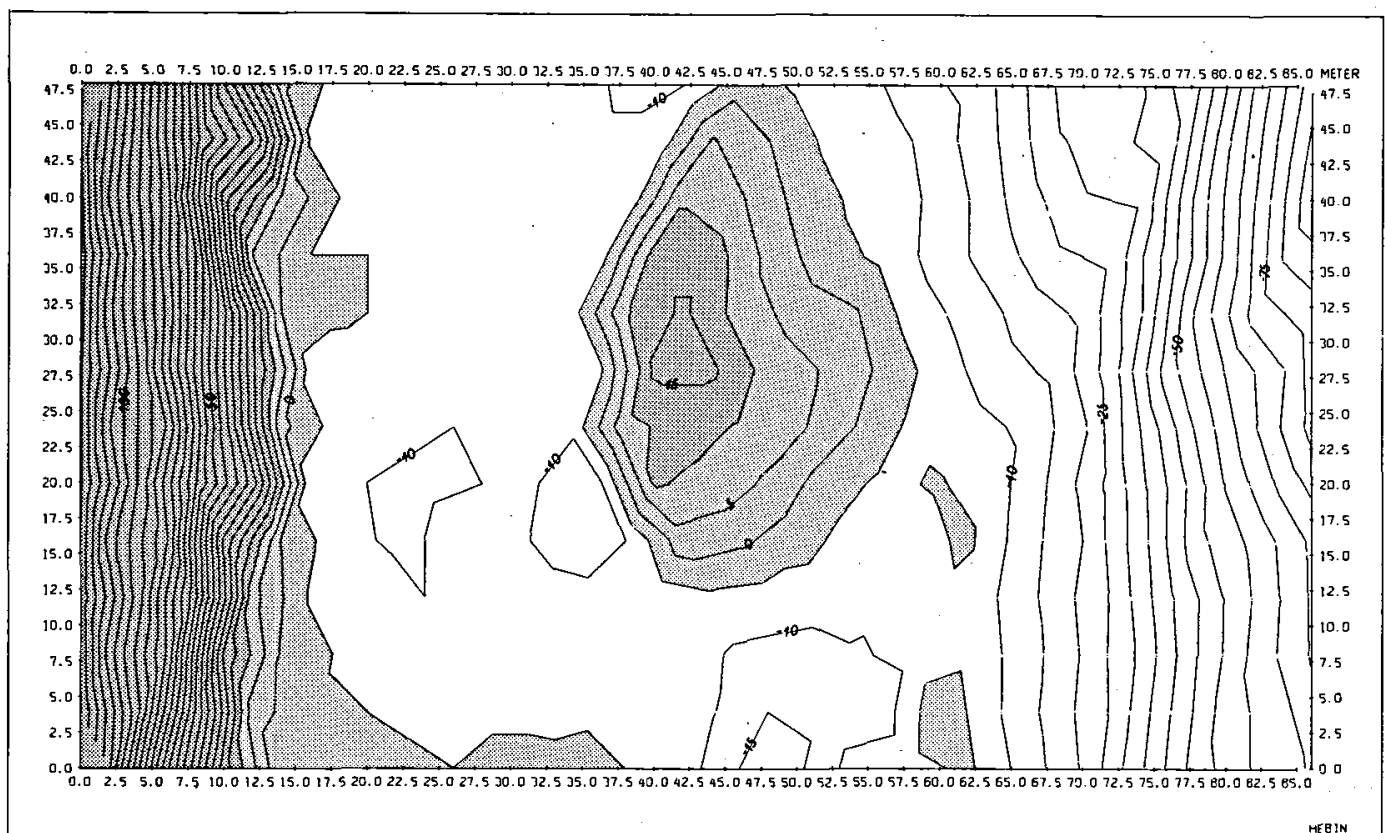

MEBIN

Fig. 9a. Contour map of the study area 14/9-1971 (contour interval: $5 \mathrm{~cm}$ ) surveyed from $1535 \mathrm{~h}$ to $1620 \mathrm{~h}$. Water level: +3 cm DNN, wind velocity: $3 \mathrm{~m} / \mathrm{sec}$, from $N N W$. The figures of ordinate and abscissa are in metres. The ordinate points NNE.
The $-5 \mathrm{~cm}$ contour delimits the nearshore bar which has the characteristic steep lee side and flat stoss side. To the south, a rip channel drains the water from the trough between the nearshore bar and the beach.

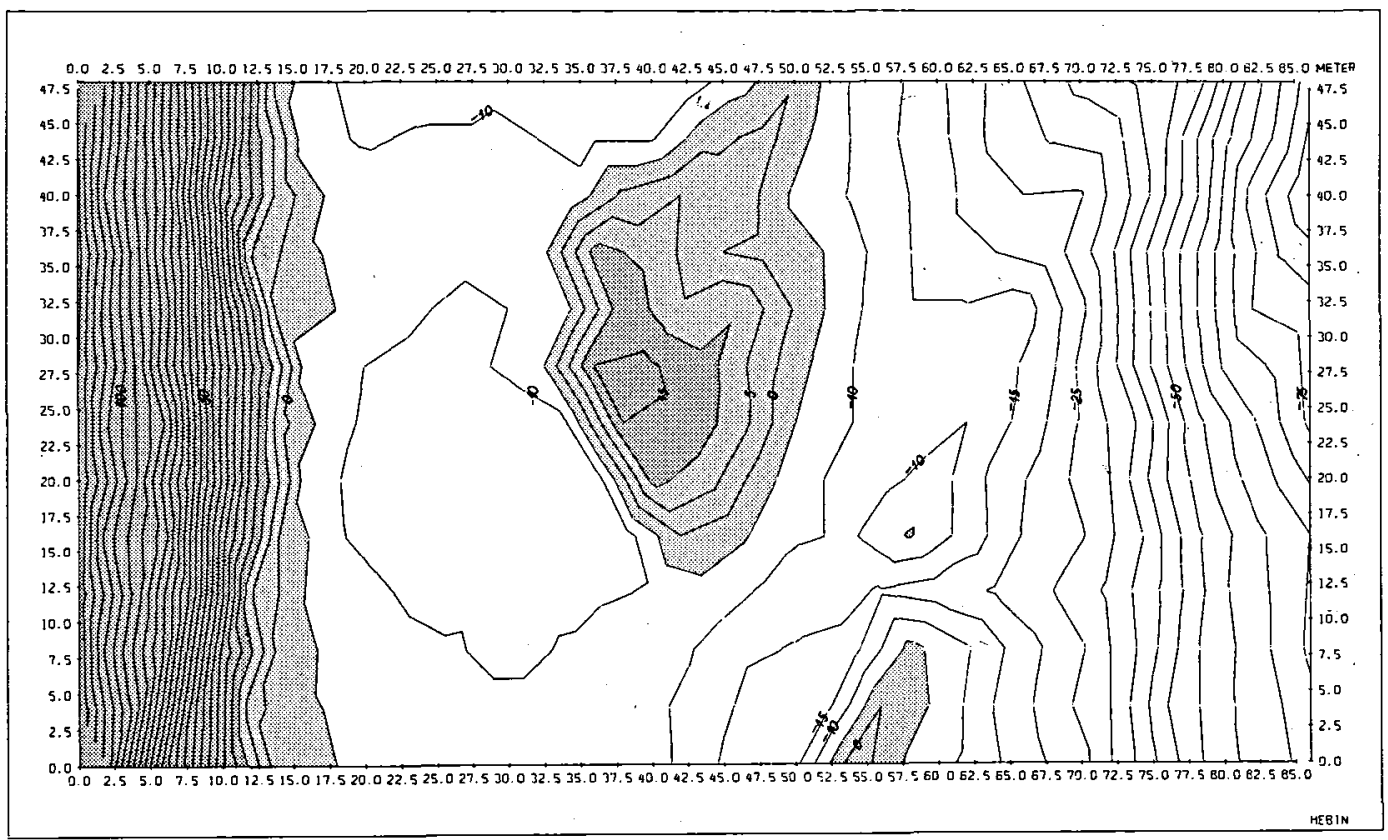

Fig. 9b. Contour map 23/9-1971, surveyed from $1955 \mathrm{~h}$ to $2110 \mathrm{~h}$. Water level: $+31 \mathrm{~cm}$, wind velocity: $10 \mathrm{~m} / \mathrm{sec}$, from SSE. 


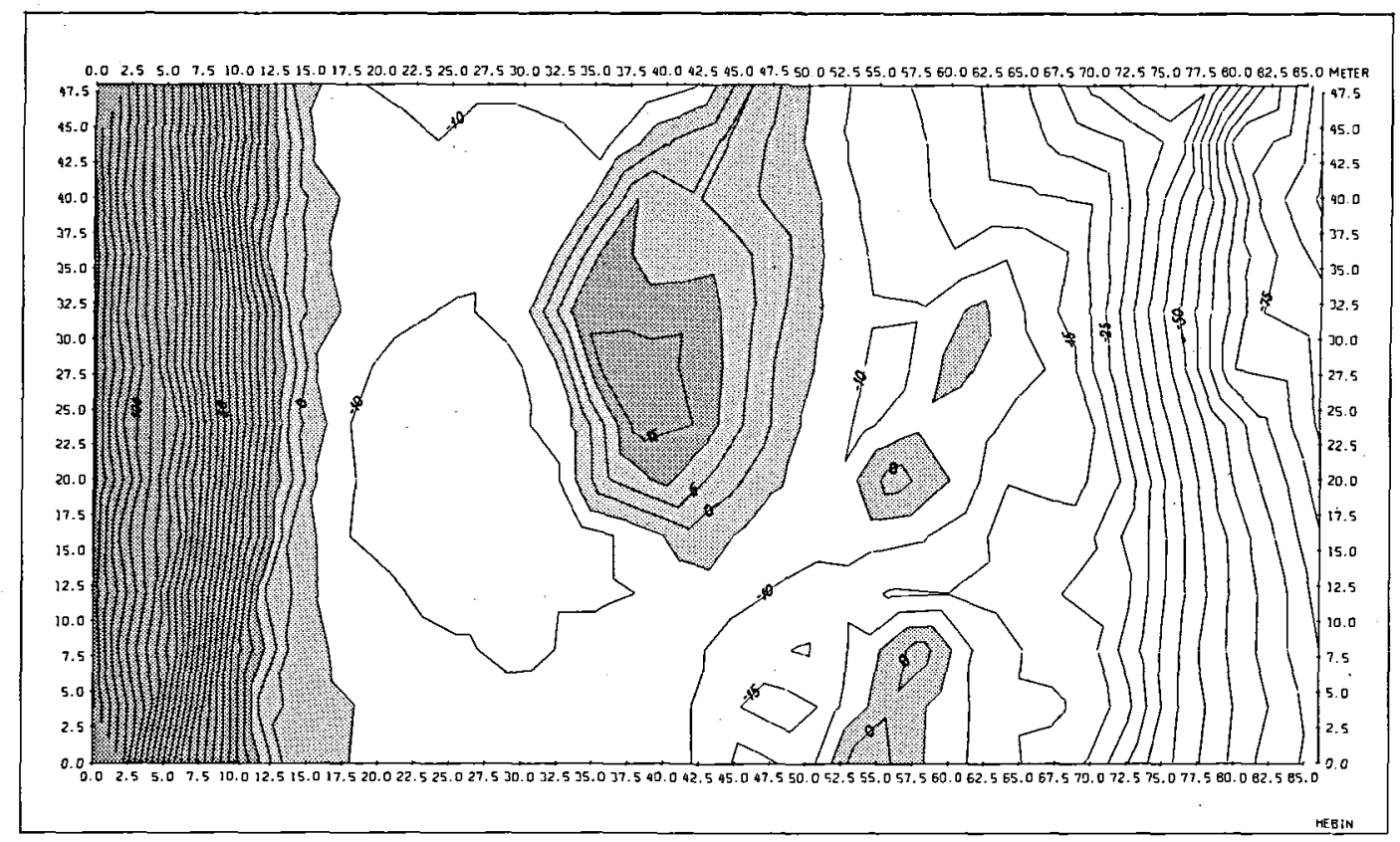

Fig. 9c. Contour map 26/9-1971, surveyed $1840 \mathrm{~h}$. Water level: $+33 \mathrm{~cm}$, wind velocity: $1 \mathrm{~m} / \mathrm{sec}$, from $\mathrm{WNW}$.

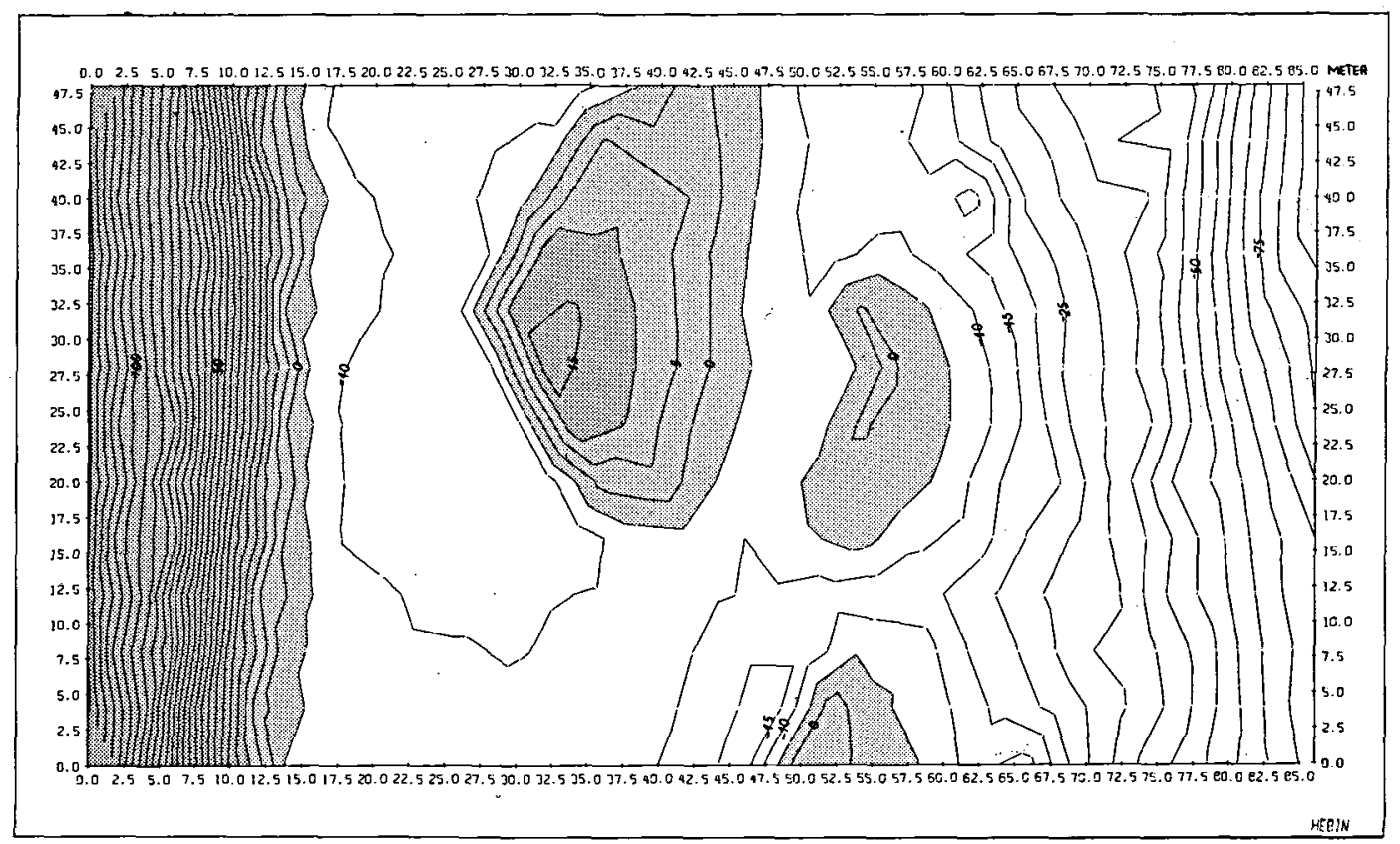

Fig. 9d. Contour map 28/9-1971, surveyed from $930 \mathrm{~h}$ to 1040 h. Water level: $+25 \mathrm{~cm}$, wind velocity: $9 \mathrm{~m} / \mathrm{sec}$, from $E S E$. 


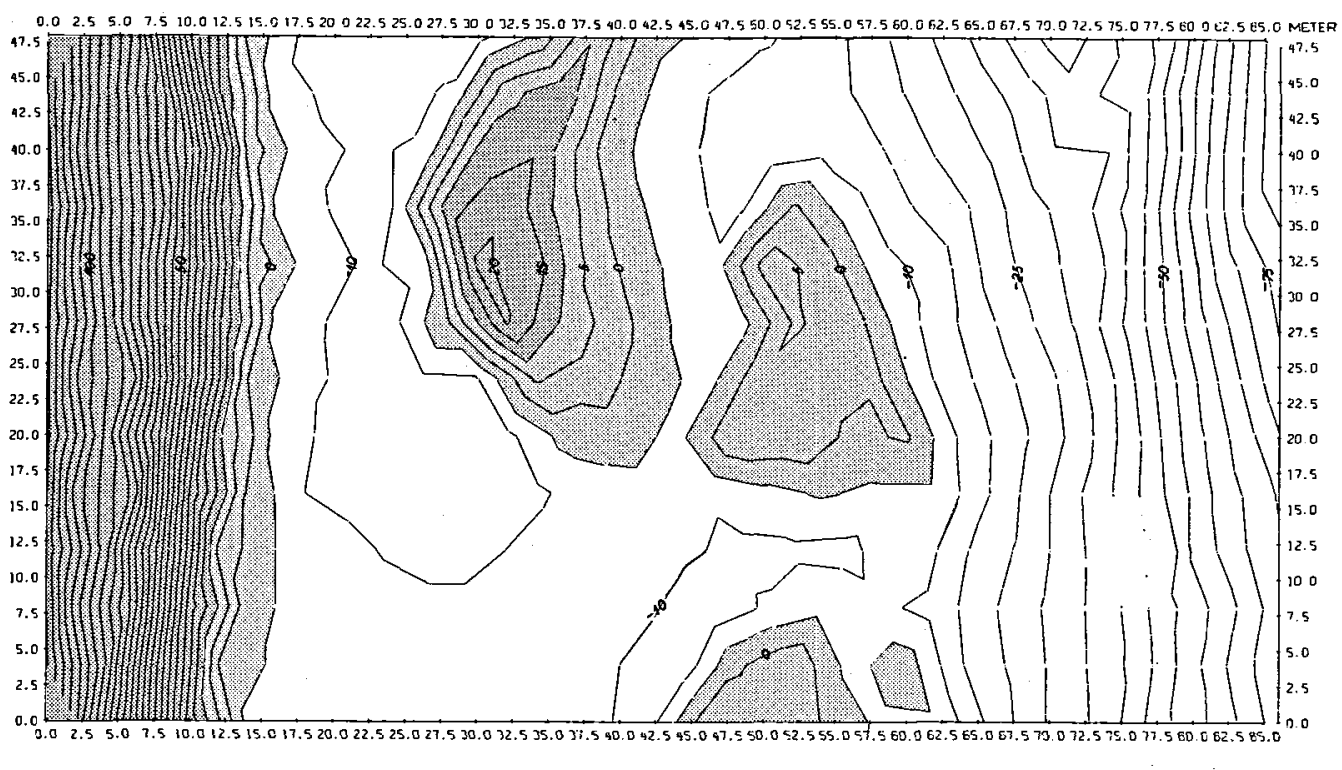

Fig. 9e. Contour map 2/10-1971, surveyed $1640 \mathrm{~h}$. Water level: $+19 \mathrm{~cm}$, wind velocity: $4 \mathrm{~m} / \mathrm{sec}$, from $\mathrm{WNW}$.

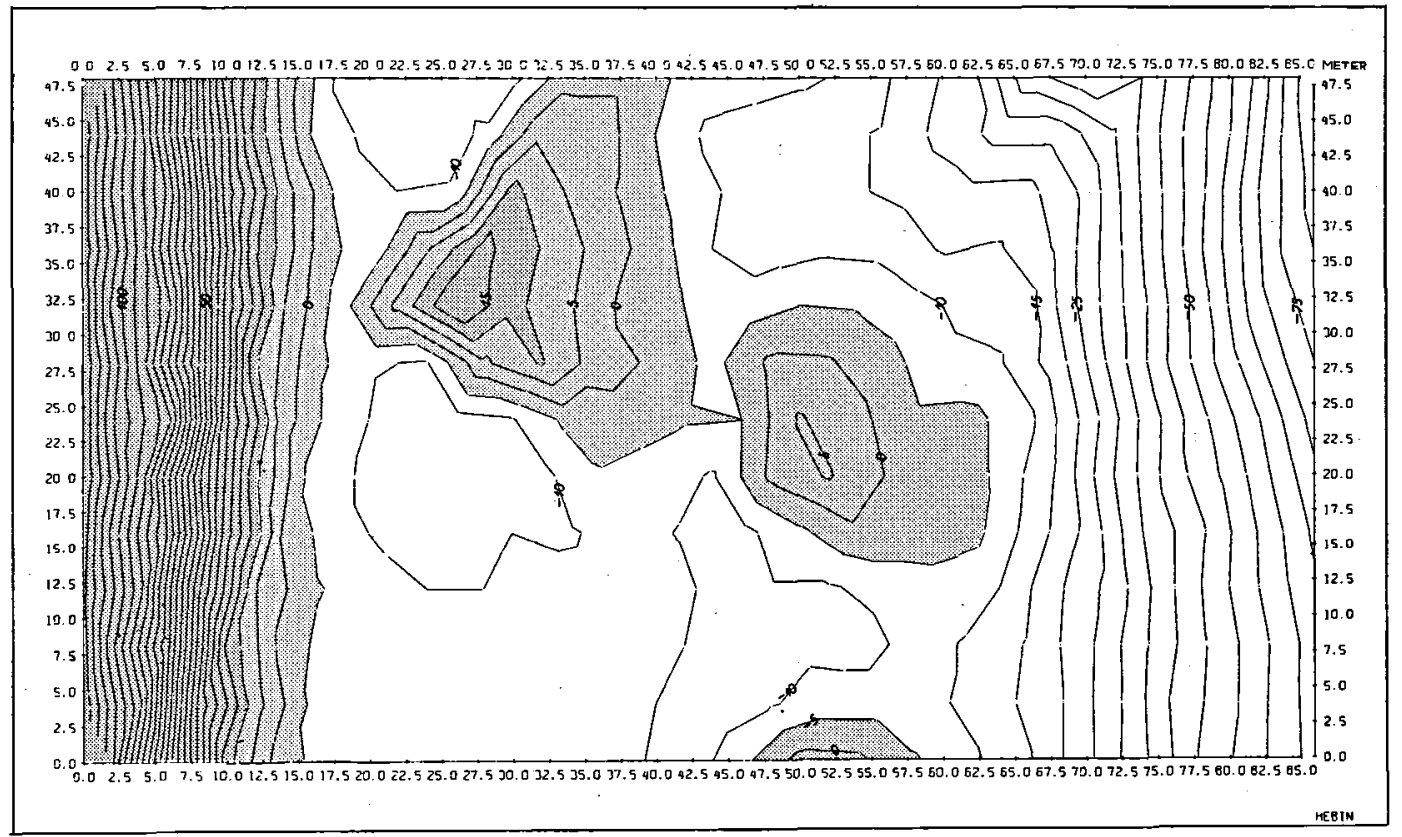

Fig. 9f. Contour map 15/10-1971, surveyed from $1620 \mathrm{~h}$ to $1705 \mathrm{~h}$. Water level: $+45 \mathrm{~cm}$, wind velocity: $2 \mathrm{~m} / \mathrm{sec}$, from $S E$. 


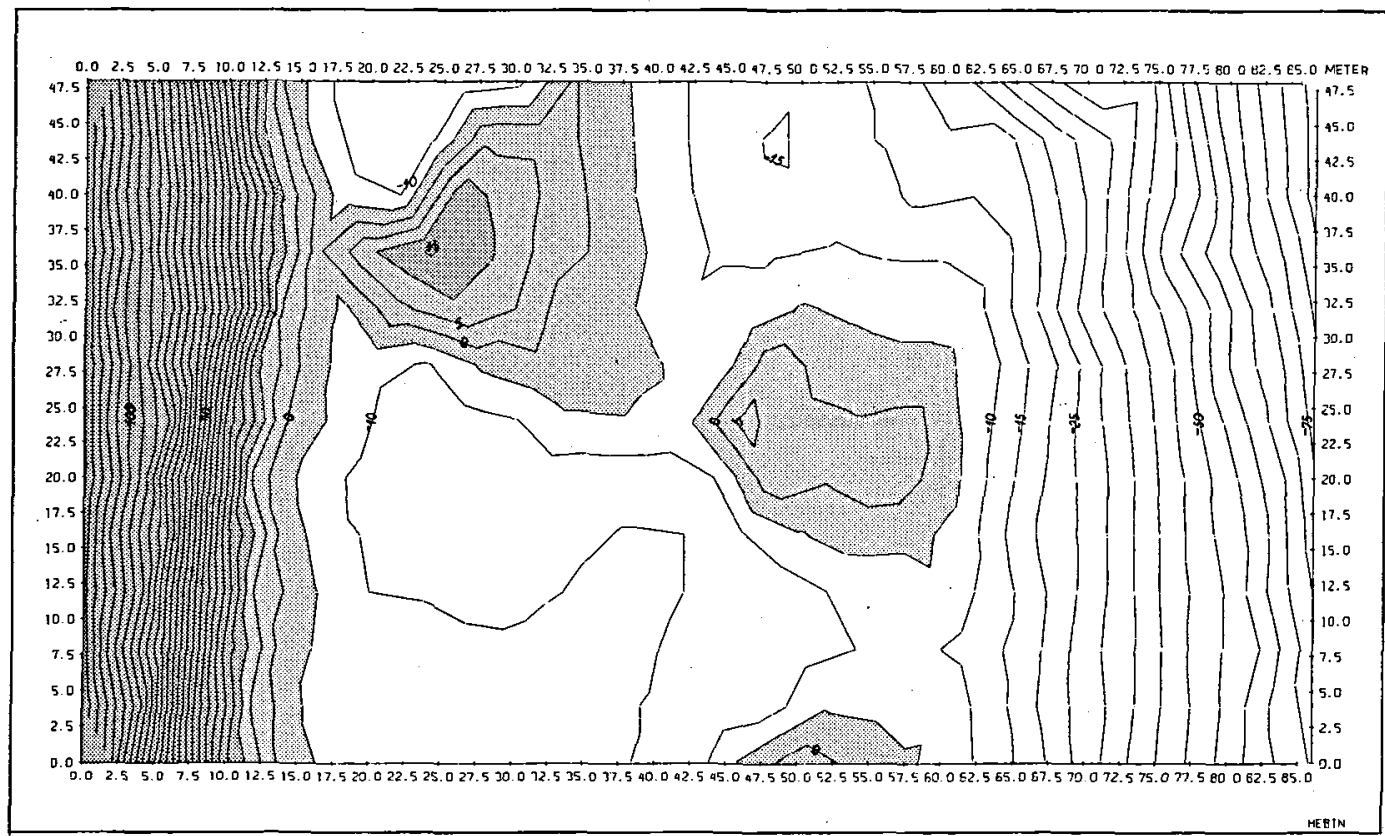

Fig. 9g. Contour map 16/10-1971, surveyed from 1725 h to

$1815 \mathrm{~h}$. Water level: $+30 \mathrm{~cm}$, wind velocity: $8 \mathrm{~m} / \mathrm{sec}$, from $S$.

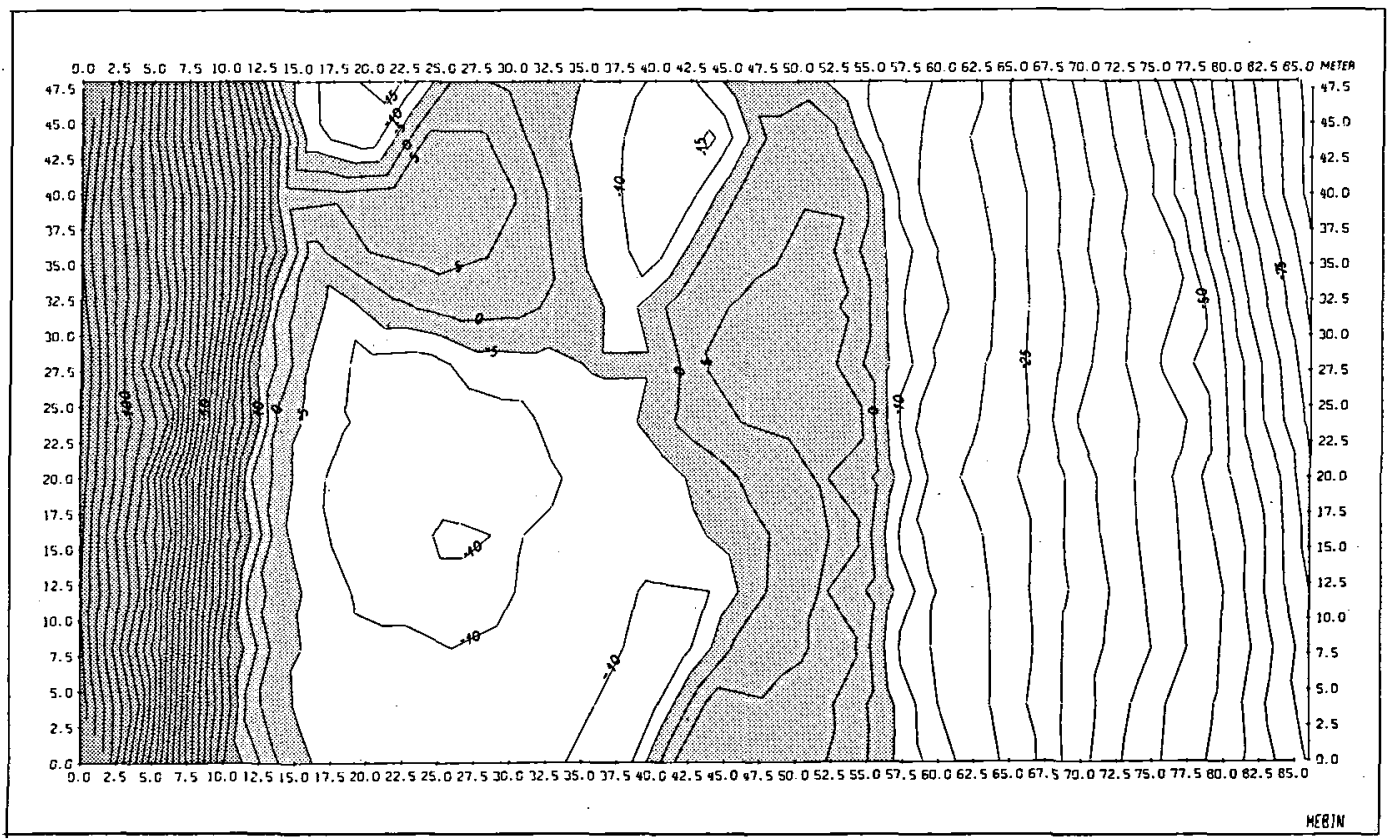

Fig. 9h. Contour map 18/10-1971, surveyed from $1115 \mathrm{~h}$ to

$1220 \mathrm{~h}$. Water level: $0 \mathrm{~cm}$, wind velocity: $9 \mathrm{~m} / \mathrm{sec}$, from $S W$. 


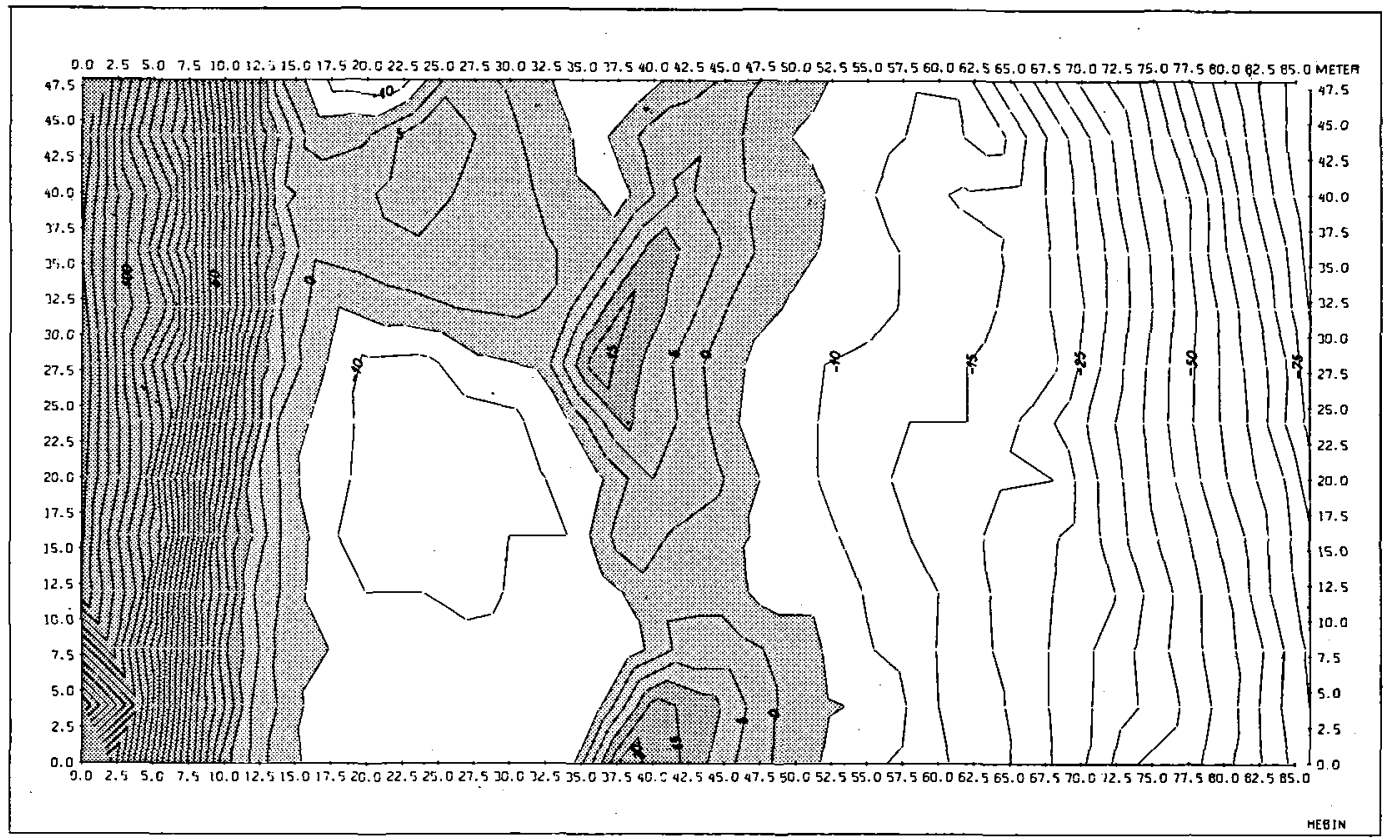

Fig. 9i. Contour map 4/11-1971, surveyed from $1100 \mathrm{~h}$ to 1200

h. Water level: $+1 \mathrm{~cm}$, wind velocity: $9 \mathrm{~m} / \mathrm{sec}$, from $W N W$.

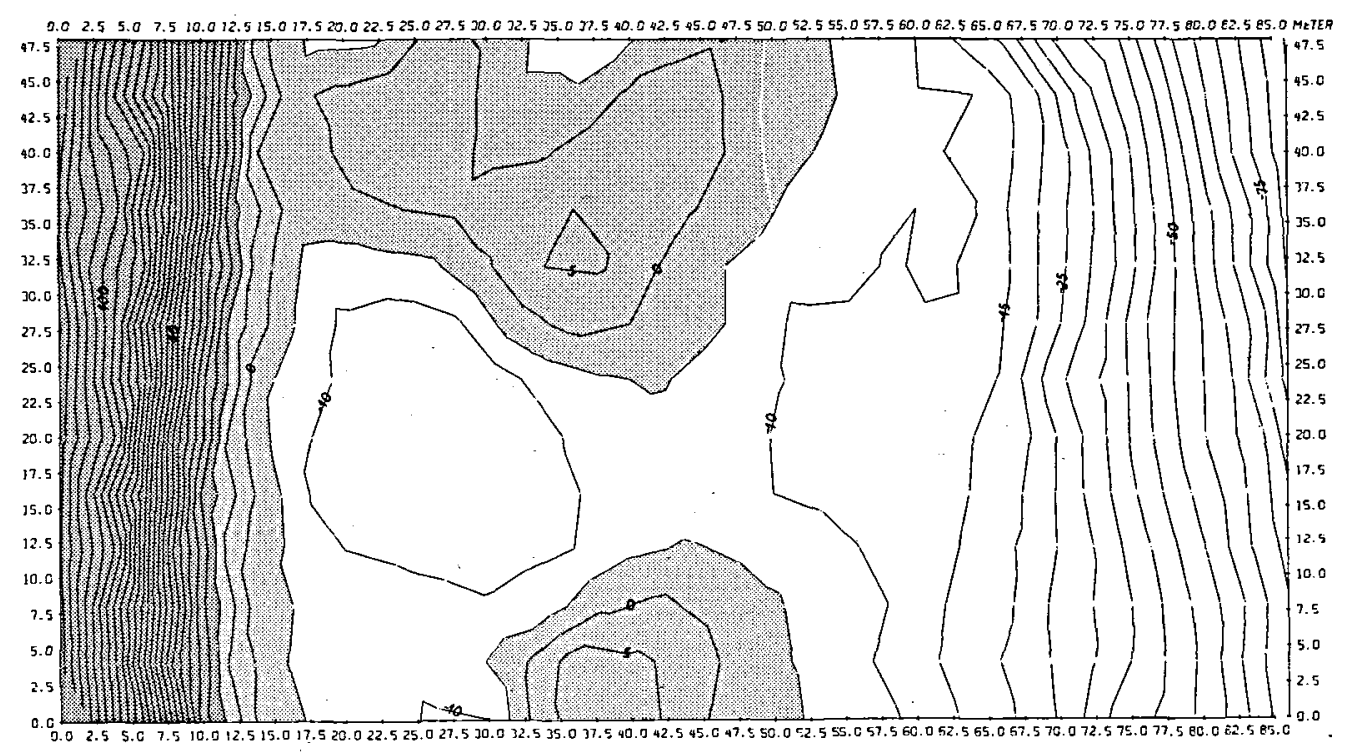

Fig. 9j. Contour map 11/11-1971, surveyed from $1020 \mathrm{~h}$ to $1120 \mathrm{~h}$. The last map of the investigation. Water level: $+3 \mathrm{~cm}$, wind velocity: $6 \mathrm{~m} / \mathrm{sec}$, from WSW. 


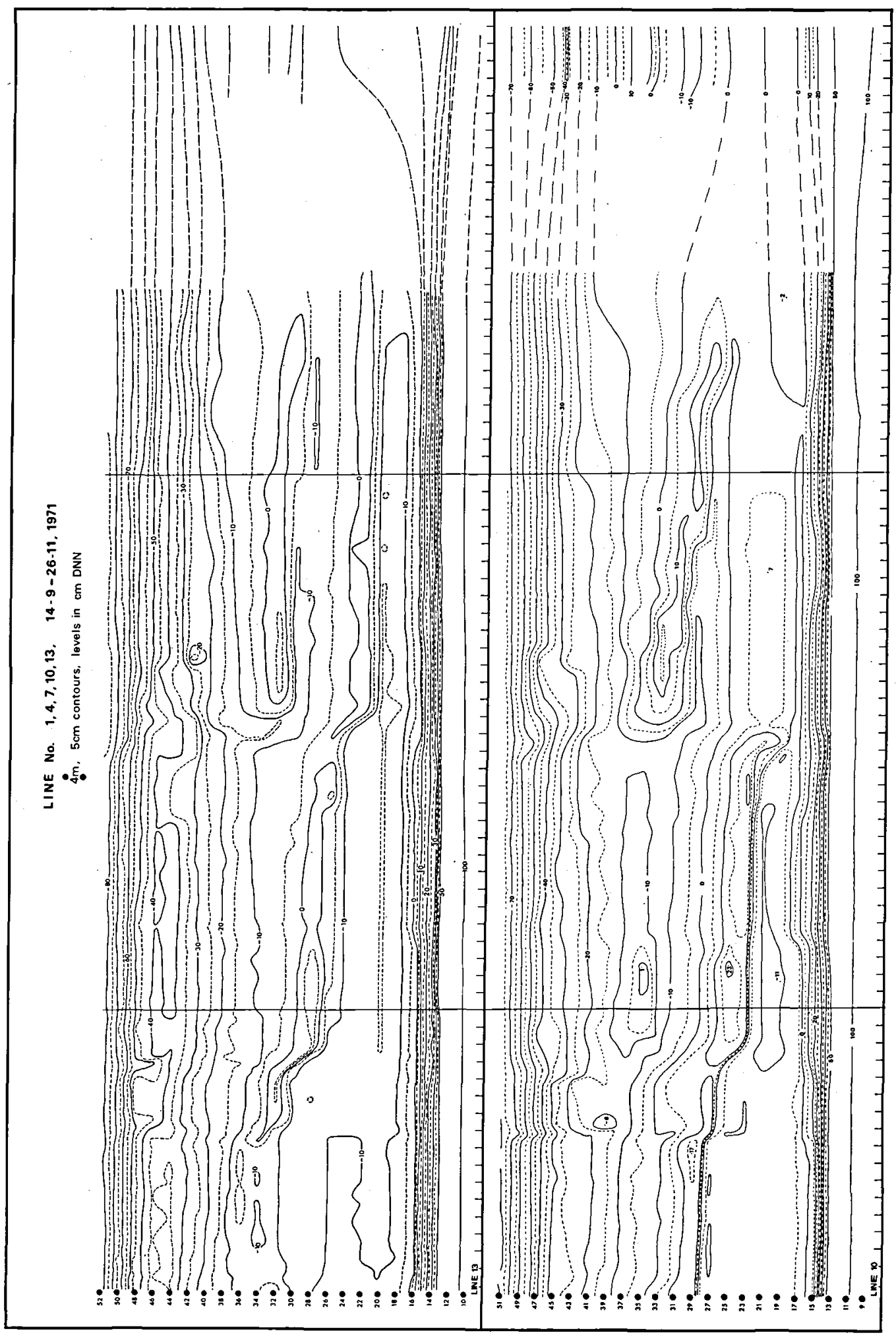

Fig. 10. T-D diagrams for the profile lines $1,4,7,10$ and 13 . Time is abscissa and the profile the ordinate, indicated by polenumbers. When an isoline is parallel with the time-axis, the location of the level is stable in relation to the shoreline. If the isoline is not parallel with the shoreline, the profile is changing and the speed of this change increases by the angle between the isoline and the $x$-axis. 


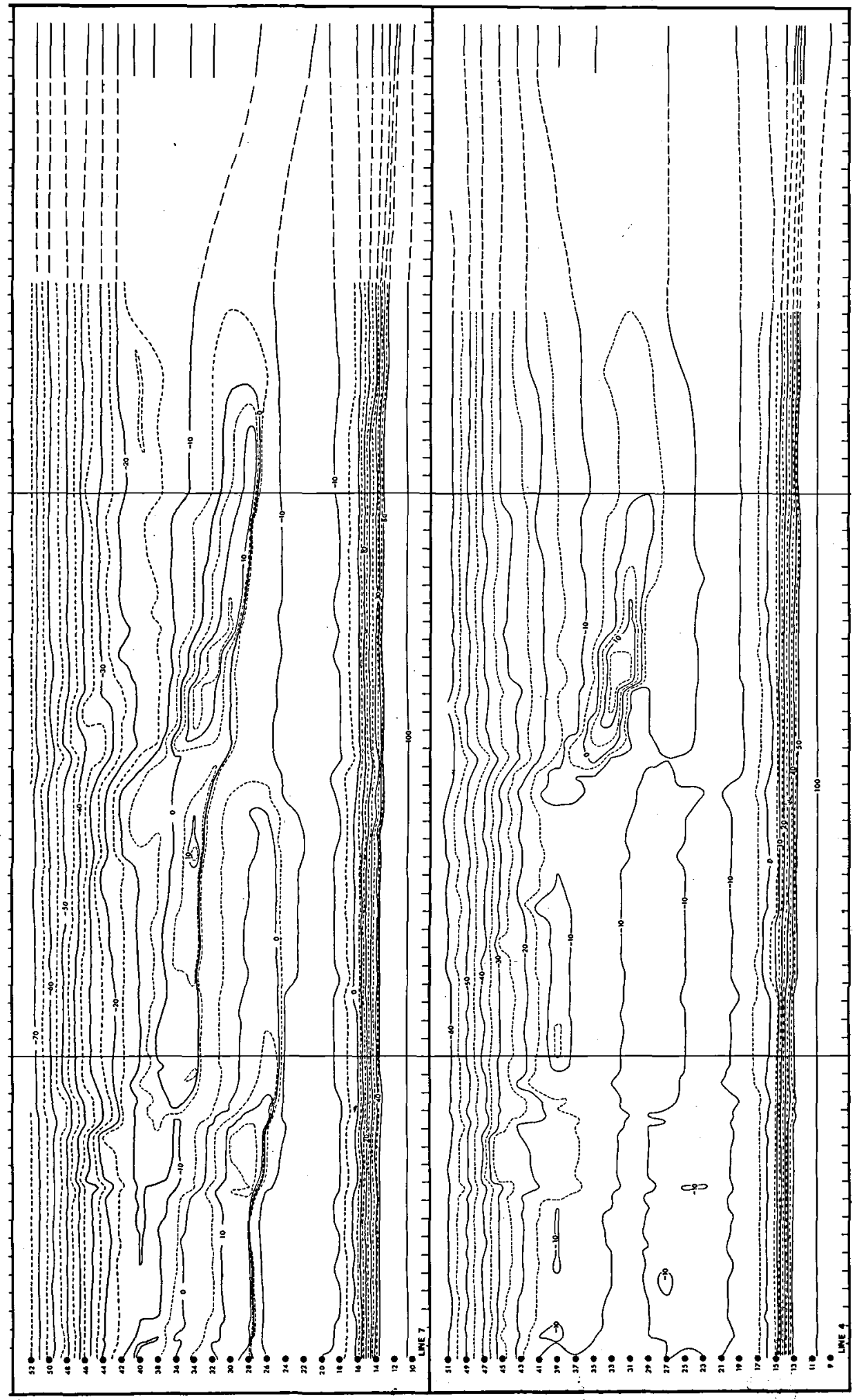

Fig. $10 b$. 


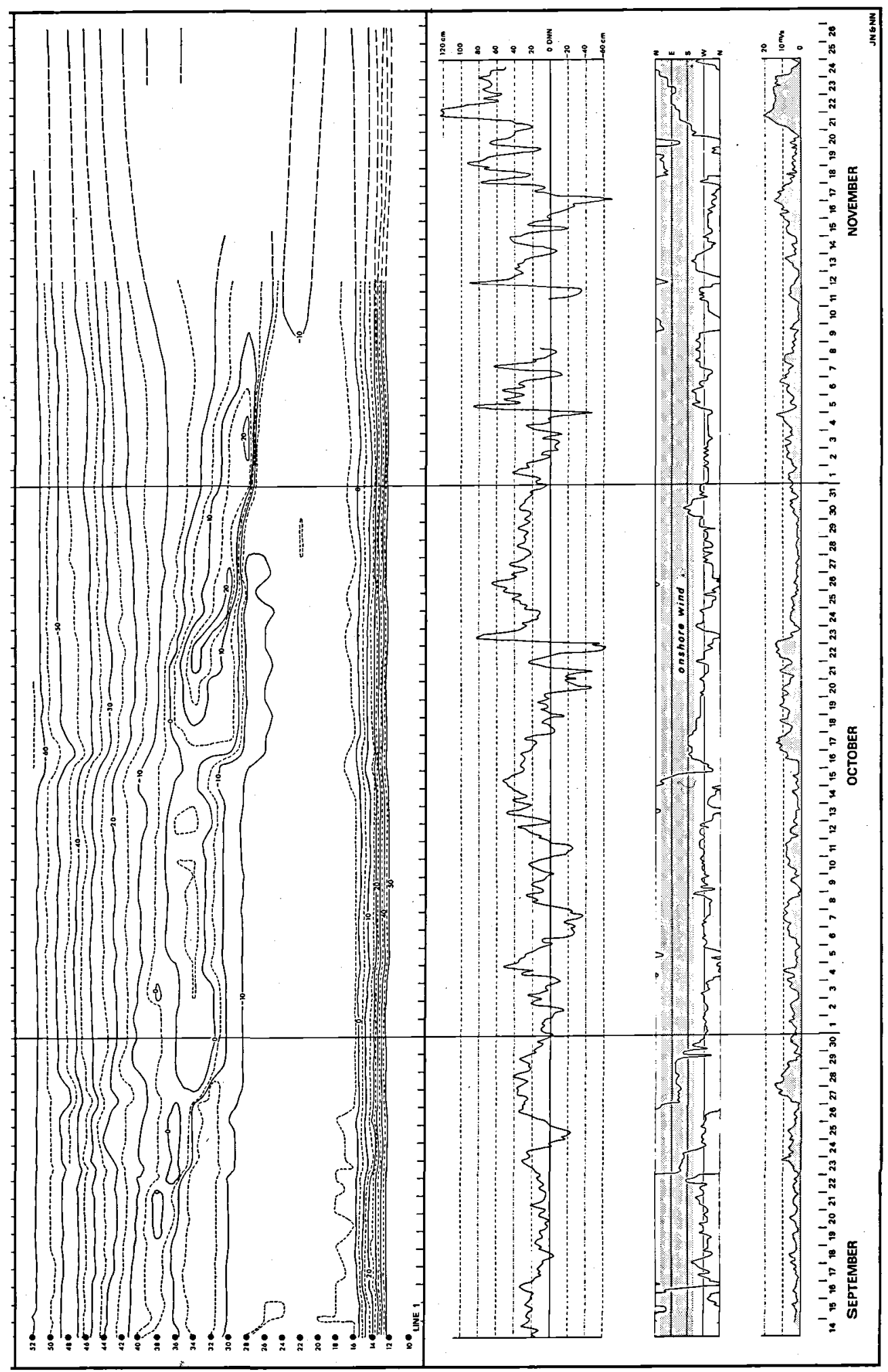

Fig. 10c. 


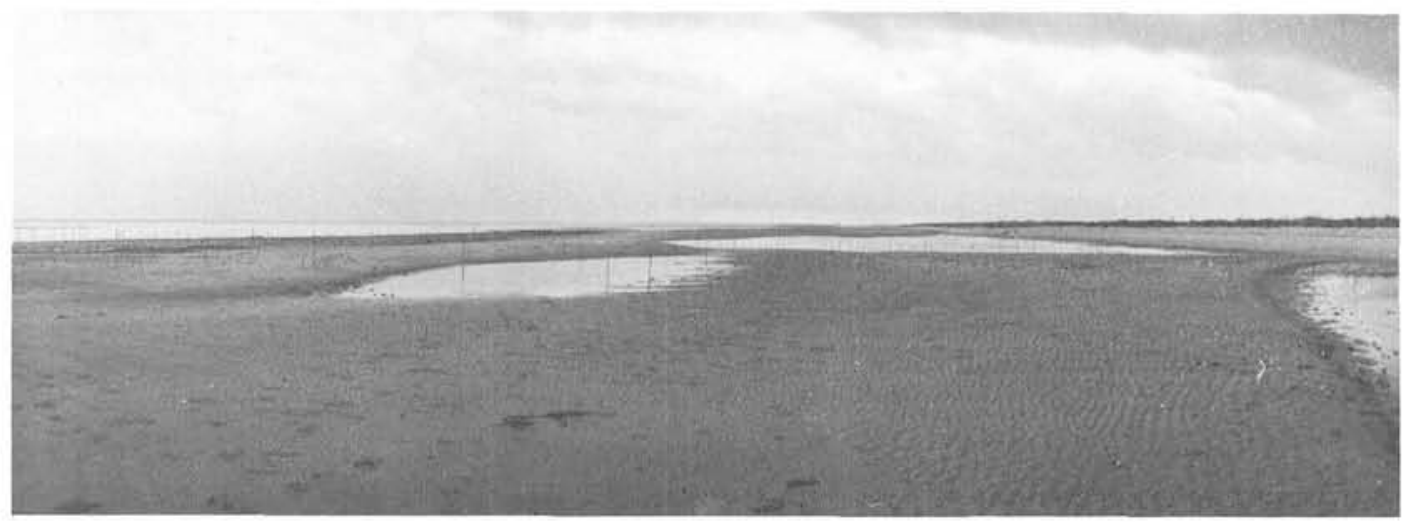

Fig. 11. The nearshore terrace at extreme low-water seen towards the south on 22/10. The innermost nearshore bar is in contact with the beach.

The morphology in the profile, line 10 (fig. 10a) shows the development of the northern part of the study area and central part of the nearshore bar. The dynamic picture in the diagram can generally be divided into two easily separated parts which represent stable and mobile phases. The active periods are: $23 / 9,27-29 / 9$ and 15-18/10. The night between 22 and $23 / 9$ the wind turned from the WSW over N to the SE and thereby became active on the coast. Simultaneously the wind speed increased from 0 to maximum $11 \mathrm{~m} / \mathrm{sec}$. and the waterlevel from 10 to 30 cm DDN (figs 10a, c). The nearshore bar front, which has moved about $1 \mathrm{~m}$ onshore during the $9^{1 / 2}$ days since the $14 / 9$ (fig. 12) now migrated about $2.5 \mathrm{~m}$ onshore during the next 24 hours from 23/9 1100 until 24/9 1100, an average speed of more than $10 \mathrm{~cm} /$ hour. Table 1 shows the recorded migration speeds from measurement to measurement.

Although 6 measurements were made $23 / 9$ it is of course only possible to get average values for the bar motion; nevertheless the following interesting thing could be noticed: the migration speed

Table 1. The migration distance and speed of the nearshore bar (from original records) and the simultaneous wave-, wind-, and water-level conditions for the period 22/9-24/9 1971, measured in line 10 . The direction of bar movements diverges $25^{\circ}$ from the direction of the profile line.

\begin{tabular}{|c|c|c|c|c|c|c|c|c|c|c|c|}
\hline \multirow{2}{*}{$\begin{array}{l}\text { Date } \\
22 / 9\end{array}$} & \multirow{2}{*}{$\begin{array}{l}\text { hour } \\
1600\end{array}$} & \multirow{2}{*}{$\frac{\mathrm{H}(\mathrm{m})}{0.04}$} & $\begin{array}{l}\text { Waves } \\
\mathrm{L}(\mathrm{m})\end{array}$ & \multirow{2}{*}{$\frac{\mathrm{T}(\mathrm{sec} .)}{0}$} & \multirow{2}{*}{$\begin{array}{c}\text { Water- } \\
\text { level } \\
(\mathrm{cm}) \\
\text { DNN } \\
8\end{array}$} & \multirow{2}{*}{$\begin{array}{c}\begin{array}{c}\text { Wind } \\
\text { veloc. }\end{array} \\
(\mathrm{m} / \mathrm{sec} \text {. })\end{array}$} & \multirow{2}{*}{$\begin{array}{l}\text { Direction } \\
{ }^{\circ} \mathrm{N} \\
160\end{array}$} & \multicolumn{2}{|c|}{$\begin{array}{l}\text { The bar's front } \\
\text { movement } \\
(\mathrm{cm})(\mathrm{cm} \\
\left.\text { adjust. } 25^{\circ}\right)\end{array}$} & \multicolumn{2}{|c|}{$\begin{array}{l}\text { The bar's } \\
\text { average speed } \\
(\mathrm{cm} / \mathrm{h} \\
(\mathrm{cm} / \mathrm{h}) \text { adjust.) }\end{array}$} \\
\hline & & & 0 & & & & & & & & \\
\hline \multirow{2}{*}{$23 / 9$} & \multirow{2}{*}{1100} & \multirow{2}{*}{0.15} & \multirow{2}{*}{5.0} & \multirow{2}{*}{2} & \multirow{2}{*}{19} & \multirow{2}{*}{5} & \multirow{2}{*}{130} & 10 & 9 & 0.2 & 0.2 \\
\hline & & & & & & & & 10 & 9 & 3.3 & 3.1 \\
\hline $23 / 9$ & 1400 & 0.4 & 7.0 & 3 & 23 & 7 & 140 & 20 & 18 & 13.3 & 12.5 \\
\hline $23 / 9$ & 1530 & 0.5 & 8.5 & 3.6 & 27 & 6 & 140 & 60 & 54 & 240 & 226 \\
\hline \multirow[t]{2}{*}{$23 / 9$} & \multirow[t]{2}{*}{1800} & \multirow[t]{2}{*}{0.5} & 11.0 & 3.4 & 28 & 7 & 150 & & & & \\
\hline & & & & & & & & 60 & 54 & 24.0 & 22.6 \\
\hline 23/9 & 2030 & 0.45 & 8.0 & 4.2 & 31 & 10 & 150 & 45 & 41 & 18.0 & 16.9 \\
\hline $23 / 9$ & 2300 & 0.3 & & 3.8 & 27 & 7 & 150 & 65 & 59 & 5.6 & 5.3 \\
\hline $24 / 9$ & 1030 & 0.2 & & 3.3 & 21 & 7 & 240 & & & & \\
\hline $25 / 9$ & 1620 & 0 & 0 & 0 & -15 & 6 & 280 & 20 & 18 & 1.1 & 1.1 \\
\hline
\end{tabular}




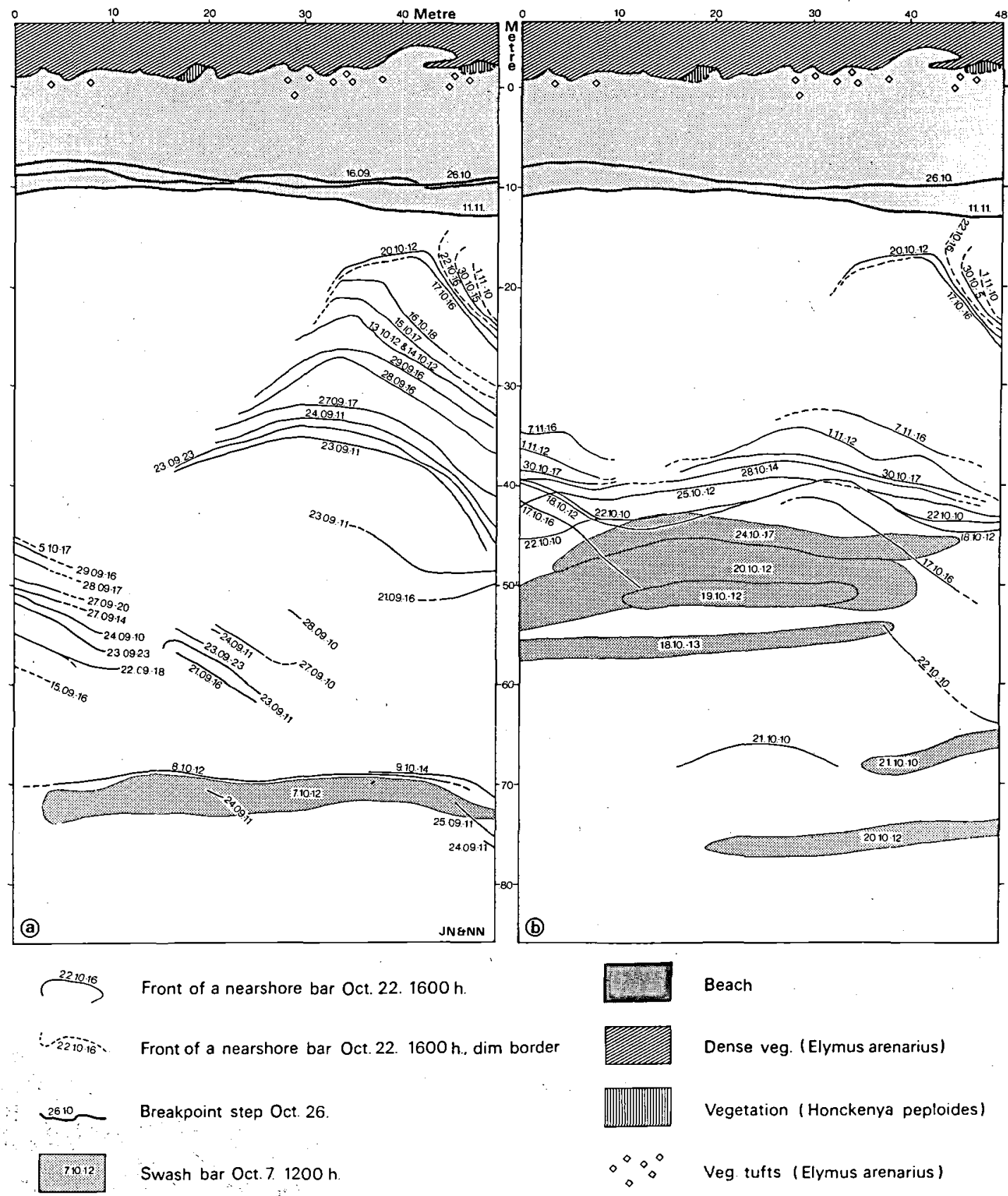

Fig. 12. The positions of the nearshore bar fronts and of the swash bars during the investigation period.

increased markedly around noon, about 2 hours after the water-level had submerged the nearshore bar, and the speed increased with the increasing wind speed and water-levels the next 6-8 hours. The decline in speed recorded after 2000 followed the decline in both water-level and wind speed. This accordance was not found, however, between the two measurements: $23 / 9$ at 2300 and $24 / 9$ at 1100 , when the bar motion decreased to $5.6 \mathrm{~cm} / \mathrm{h}$. The explanation must be the changing wind direction (24/9 at 0400) from the active SSE wind to the passive SW direction. 
Table 2. The migration distance and speed of the nearshore bar and the simultaneous wave-, wind-, and water-level conditions for the period 25/9-30/9 1971, measured in line 10.

\begin{tabular}{|c|c|c|c|c|c|c|c|c|c|c|c|}
\hline Date & hour & $\begin{array}{l}\text { waves } \\
H(m)\end{array}$ & $\mathrm{L}(\mathrm{m})$ & $\mathrm{T}(\mathrm{sec})$. & $\begin{array}{l}\text { water- } \\
\text { level } \\
\text { (cm) } \\
\text { DNN }\end{array}$ & $\begin{array}{l}\text { wind } \\
\text { veloc. } \\
\mathrm{m} / \mathrm{sec} \text {. }\end{array}$ & $\begin{array}{c}\text { Direction } \\
{ }^{\circ} \mathrm{N} \\
-\end{array}$ & \multicolumn{2}{|c|}{$\begin{array}{l}\text { The bar's front } \\
\text { movement } \\
\text { (cm) (cm } \\
\text { adjust. } 30^{\circ} \text { ) }\end{array}$} & \multicolumn{2}{|c|}{$\begin{array}{l}\text { The bar's } \\
\text { average speed } \\
(\mathrm{cm} / \mathrm{h} \\
(\mathrm{cm} / \mathrm{h}) \text { ad just.) }\end{array}$} \\
\hline \multirow[t]{2}{*}{$25 / 9$} & 1620 & 0 & 0 & 0 & -15 & 5 & 280 & & & & \\
\hline & & & & & & & & 30 & 26 & 1.1 & 1.0 \\
\hline $26 / 9$ & 1840 & 0 & 0 & 0 & 32 & 1 & 300 & 80 & 69 & 5.2 & 4.5 \\
\hline \multirow[t]{2}{*}{$27 / 9$} & 1015 & 0.3 & 9.5 & 3.8 & 24 & 8 & 120 & & & & \\
\hline & 1310 & 05 & 106 & 41 & 30 & 12 & 120 & 95 & 82 & 32.6 & 28.2 \\
\hline $27 / 9$ & & & & & & & & 70 & 60 & 18.0 & 16.0 \\
\hline $27 / 9$ & 1650 & 0.6 & 10.2 & 3.9 & 37 & 12 & 130 & 30 & 26 & 10.4 & 9.0 \\
\hline $27 / 9$ & 1950 & 0.4 & 9.1 & 3.3 & 36 & 12 & 130 & 275 & & 18 & 150 \\
\hline \multirow{2}{*}{$28 / 9$} & 1005 & 0.4 & 10.0 & 3.5 & 25 & 9 & 110 & & & 10.0 & 10.2 \\
\hline & & & & & & & & 51 & 44 & 13.0 & 11.3 \\
\hline $28 / 9$ & 1400 & 0.4 & 8.9 & 3.0 & 39 & 10 & 130 & 60 & 52 & 17.1 & 14.9 \\
\hline $28 / 9$ & 1730 & 0.4 & & 4.7 & 41 & 10 & 110 & 144 & 124 & 61 & 53 \\
\hline \multirow[t]{2}{*}{$29 / 9$} & 1615 & 0.2 & 8.1 & & 33 & 1.8 & 150 & & & & \\
\hline & & & & & & & & 10 & 9 & 0.5 & 0.5 \\
\hline $30 / 9$ & 1100 & 0.1 & 7.0 & 3.0 & 7 & 5 & 240 & & & & \\
\hline
\end{tabular}

$27 / 9$ and $29 / 9$ the forms were considerably displaced on the nearshore, and the highest bar front speed was registered $27 / 9$ at noon $(32.6$ $\mathrm{cm} / \mathrm{h}$ ) as table 2 shows.

When the water-level was high and the nearshore bar submerged, water movements were quite different from the direction of the incoming waves generated on the nearshore terrace. On the 27/9 two current observations were performed. By means of a balanced float the water movements could be surveyed in great detail because of the permanent grid net.

On the landward part of the nearshore terrace, where the waves are transformed into surf waves (at -20 to $-30 \mathrm{~cm} \mathrm{DNN}$ ) the floats follow the courses determined by the wave-generated northward current, by the breaking surf waves and the drag of the SE-wind on the water surface. The pattern of the current courses (fig. 13a) is apparently not influenced by a normal return current in the rip channel. On the contrary, the highest landward velocities are found just here $(70-100 \mathrm{~cm} / \mathrm{sec}$.). Within the nearshore bar area there is a clear trend to increased speed ( 30 $\mathrm{cm} / \mathrm{sec}$.) in a northward direction; this suggests the presence of a rip channel north of the investi- gation area. Only floats that have passed through the channel will strand on the shore.

On the velocity map (fig. 13b) the wind speed has increased somewhat and the convexity of the current courses is less evident. The difference between the two situations is primarily to be found in the conditions prevailing at the rip channel; as fig. $13 \mathrm{~b}$ shows, there is an apparently active rip current (no currents head into the channel). The rip channel just $\mathrm{N}$ of the study area seems to be partly out of function, however, as all current courses point towards land.

It was demonstrated that rip channels in waters as shallow as these are governed by the same processes - with alternating active periods - as the well-known, larger rip channels in the break point bars. The investigation showed also that the magnitude of these currents, generated so close to the shore, are sediment-transporting and erode both behind the nearshore bar and into the rip channel. Note the topographic development of the nearshore bar on the current velocity maps.

Between $30 / 9$ and 13/10 the nearshore bar only migrated $1.7 \mathrm{~m}$ onshore; the graphs for this period show a general low water-level and an offshore wind. On 13/10 the water-level rose to 

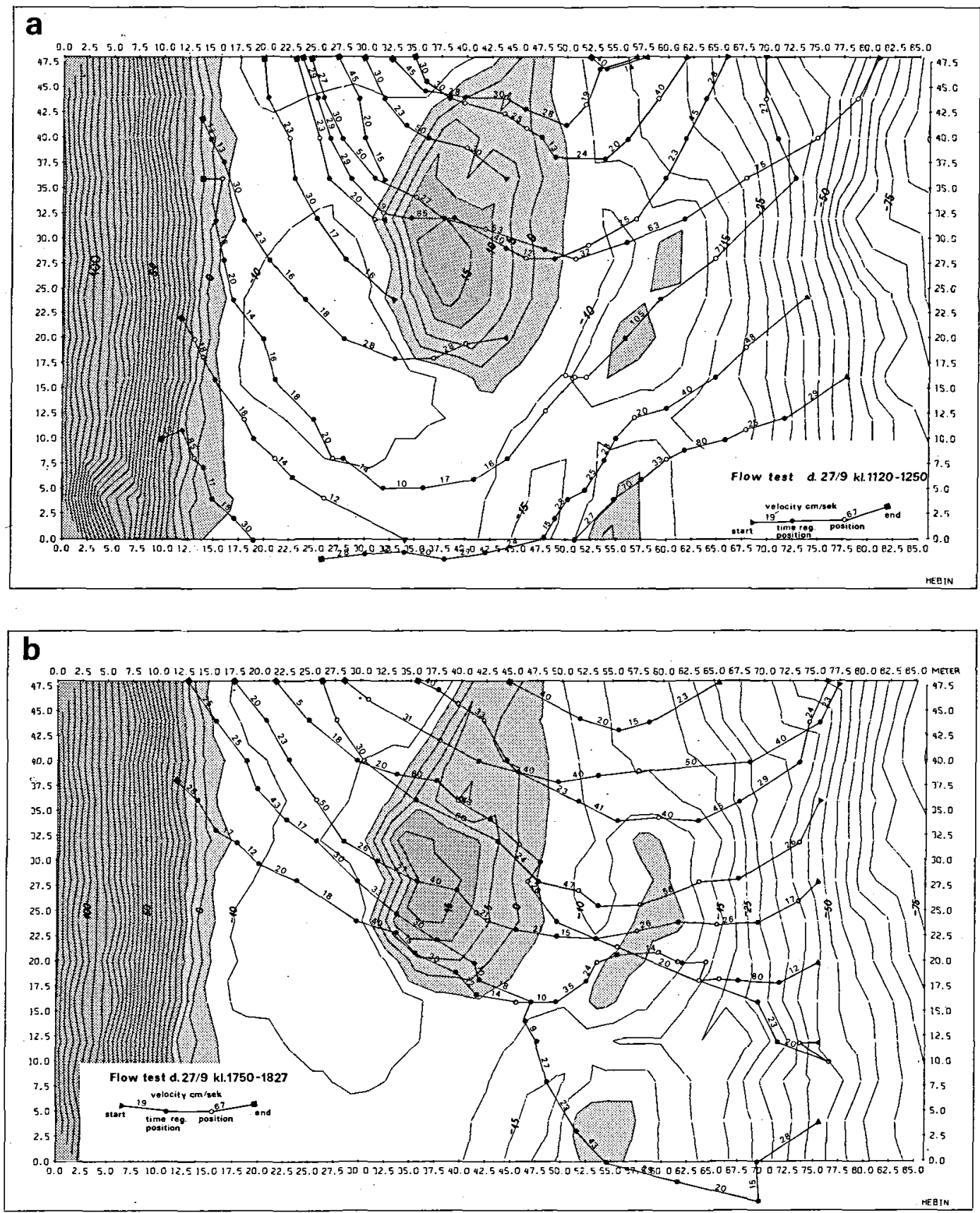

Fig. 13. Float tests made on 27/9. The courses of the float show the current movements around the nearshore bar during a dynamically active period. a) Records from $1120 \mathrm{~h}$ to $1250 \mathrm{~h}, \mathrm{~b}$ ) from $1750 \mathrm{~h}$ to $1827 \mathrm{~h}$. The Contour maps were surveyed a: from 950 $h$ to $1045 \mathrm{~h}, \mathrm{~b}$ : from $1625 \mathrm{~h}$ to 1715 .
Notice that the direction of the float courses farthest off are $S W$ and almost at right angles to the advance of wind and waves. This can be explained by a south-going coastal current, which generally occur in this part of the day during wind from the E-SE sector. 
$+50 \mathrm{~cm}$ DNN, but the wind had a direction that was inactive for the shore, and the wave activity was very low. These conditions changed during the night between 14 and $15 / 10$, when the high water-level was combined with a change in wind direction from $\mathrm{N}$ to $\mathrm{E}$ and on to $\mathrm{S}$. Although the wind only blew $1-2 \mathrm{~m} / \mathrm{sec}$., the wave observations $15 / 10$ at 1610 show wave heights of $15 \mathrm{~cm}$ and a wave period of $4.5 \mathrm{sec}$. Measurements on the nearshore bar front during the period $14 / 10$ at 1200 until $15 / 10$ at 1600 show, however, that although small, these waves were sufficiently high to induce a front movement in line 10 of more than $2 \mathrm{~m}$. On $16 / 10$ before noon the development accellerated, as the wind speed increased from $1.5 \mathrm{~m} / \mathrm{sec}$. to more than $10 \mathrm{~m} / \mathrm{sec}$, and the wind turned straight south; i.e. it becomes wave-generating although the entrance angle in relation to the coast normal was very wide. The bar was now covered with $10-15 \mathrm{~cm}$. water, and the wave heights just seaward of the nearshore bar were measured to be $30-35 \mathrm{~cm}$ and the wave period to be 3.3 seconds. These small and steep, short-period waves proved to be very effective in displacing the nearshore bar, and the isolines $(+5,+10 \mathrm{~cm} \mathrm{DNN})$ curved markedly onshore during 16/10 (fig. 10).
The further isoline course shows a stabilization of the area; this may seem odd, as the water-level is still high and the waves $25-30 \mathrm{~cm}$ high. The explanation is seen in fig. 12, where the direction of the migrating bar turns sharply NNW in good accordance with the refracted small waves of high frequency from the south.

After the fusion of bar and beach, the changes in forms were insignificant near the beach (18/10-23/10). Further seaward, however, a swash bar was being built up (figs $9 \mathrm{~h}, 14$ ), as the water-level in this period was very low, and the nearshore terrace almost horizontal. Any wave will be a constructive agent under such conditions, i.e. transport sediments onshore and contribute to increase the nearshore gradient. On $23 / 10$ the swash bar was overwashed and was immediately transformed into a nearshore bar (steep leeside) (fig. 9i).

The correlation between variations in weather and the forms in line 1 follows the pattern of the bar located to the north; the same cannot be said of the morphology in line 4 . The course of the isolines is seen to be disturbed only during the period $18-24 / 10$ where the rip channel dried up and sediments were deposited in it, producing a swash bar ( +15 to $+20 \mathrm{~cm} \mathrm{DNN}$ ) (fig. $9 \mathrm{~h}$ ). The

Fig. 14. Exposed swash bar and rip channel in the nearshore terrace.

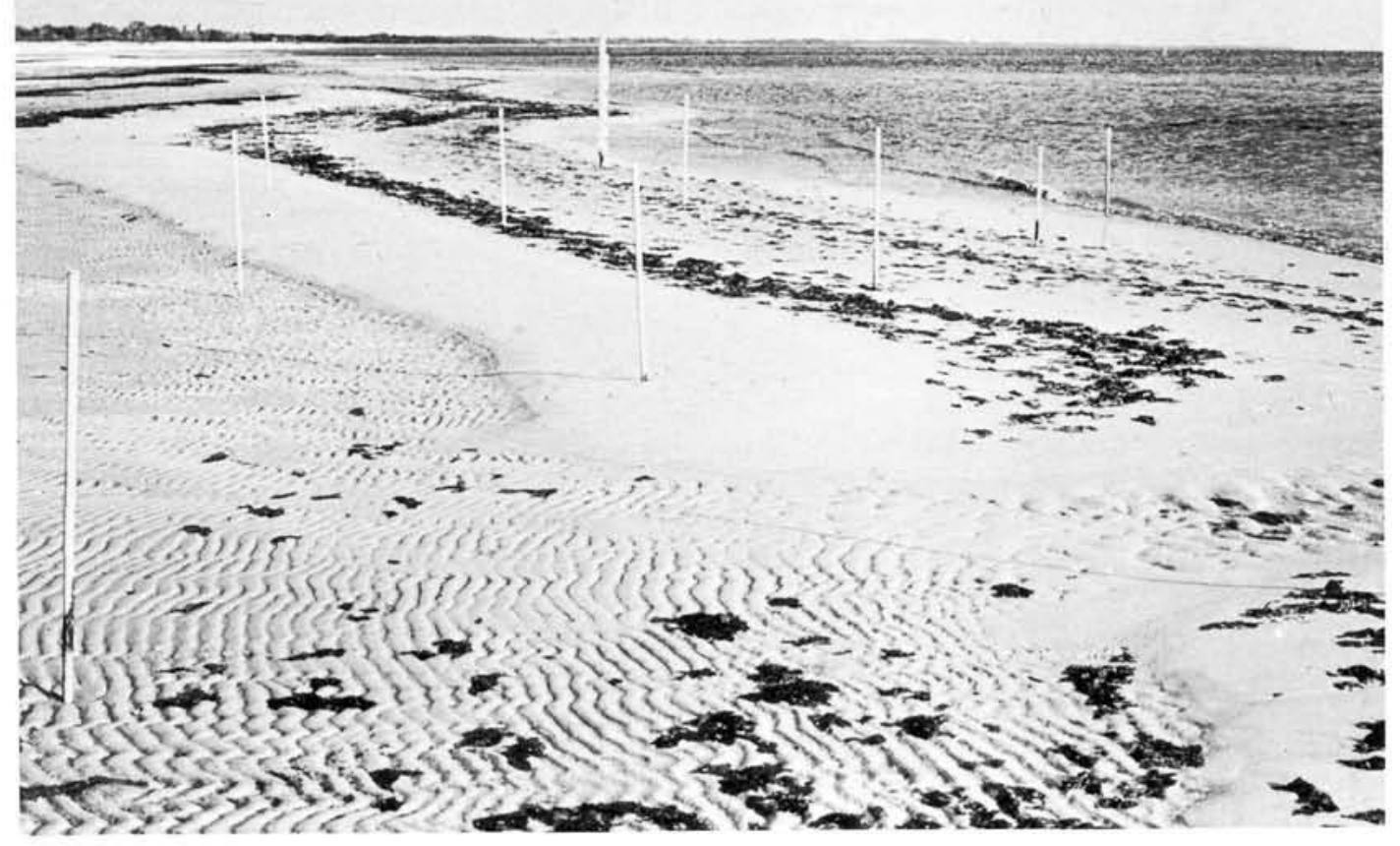




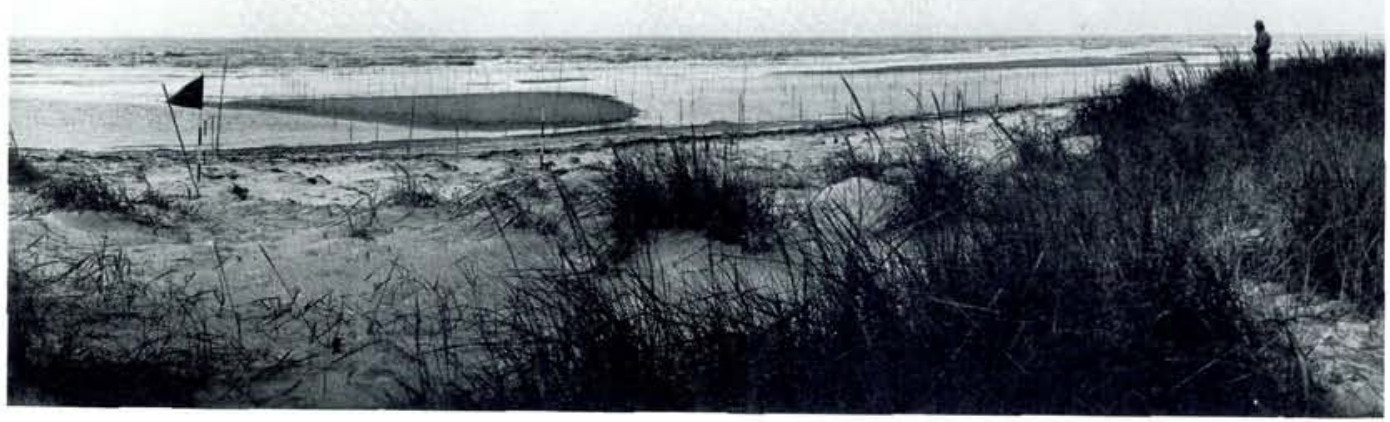

Fig. 15. Nearshore bars in the investigation area separated by the rip channel in line 4.

transformation into a nearshore bar was also taking place, but here the level declined so much in relation to the nearshore bars north and south of it that the rip channel was re-established down to its first depth (about $-10 \mathrm{~cm} \mathrm{DNN}$ ) (figs $9 \mathrm{j}$, $15)$.

Generally speaking, the current velocities in the rip channel were low $(<10 \mathrm{~cm} / \mathrm{sec}$.) and lay only a few times above the critical threshold values for sediment motion. When the southern bar nevertheless could not traverse the channel, it was due to two things: During moderate wave situations, but with a water-level just covering the bars, surf waves will be created that are sufficiently effective to transport sediments across the bar. In the rip channel, however, the depth was so much higher that the surf waves did not break. Part of the sediments transported across the southern bar were taken out through the rip channel in spite of the low current velocities, as some sediments were still in suspension when the surf waves reached the lee front of the bar. During decreasing water-level, the rip channel narrowed and for shorter periods - before totally drying up - assumed a river-like character, (fig. $10 \mathrm{~b})$; the erosion of the leeside of the southern bar was then obvious.

The isolines are very stable on the outermost part of the nearshore terrace and the nearshore face, except during periods with strong onshore winds $(23 / 9,27-28 / 9$, and $16-17-18 / 10)$. This means that the profile reacts very rapidly (few hours) - especially on the nearshore face - on changes in wave- and water-level parametres, and during this process a "normal weather profile" and a "storm profile" are created. The following temporary transport of material, onshore or offshore, may generate new forms. This can also be observed at several places in the T-D diagrams; as these new forms are preserved simultaneously with the re-establishment of the seaward located part of the nearshore terrace, this must mean a net surplus of sediments. This will later be demonstrated by means of volume calculations.

Concluding remarks on formation and morphology of the nearshore bar

A nearshore bar is formed during extreme windand water-level conditions. During high water-levels and strong onshore winds, initial break point bars develop outermost on the nearshore terrace as symmetrical, low, ridge-formed accumulations which, towards the end of the extreme situation, will be transformed into the assymetrical shape of the nearshore bar. The bar's chances of survival depend on the subsequent period with quiet wind conditions and normal water-levels being long enough to allow the bar to migrate 
away from the shoreface and on to the nearshore terrace, still increasing in size.

During offshore winds and low water-levels the initial part of the nearshore bar may arise from a swash bar in different places on the nearshore terrace, dependent on the water-level. The subsequent normal water-levels will then transform the swash bar into a nearshore bar. The chance that this nearshore bar will exist for a longer period depends on the location of its 'birth' (fig. 12).

Having left the shoreface and entered the nearshore terrace, the bar migrates towards the shore during any wave situation, if covered with water, or overwashed by the swash; i.e. the bar migrates onshore under the influence of both storm waves and swells. The migrating speed of the nearshore bar varies from a few $\mathrm{cm}$ to 30 $\mathrm{cm} / \mathrm{h}$.

The characteristic cross profile of the nearshore bar with its steep leeside and flat stoss side is normally maintained under all dynamic conditions, although the gradient of the uppermost part of the stoss side varies with the wave parametres, so that steep waves will level the top to an almost horizontal plane, whereas constructive waves (swells) will increase the top level and thereby also the gradient of the stoss side.

The nearshore bar starts as long ridges parallel to the coast, but in Køge Bugt they do not remain stable. Just after advancing onshore, the ridge splits up into a number of minor islands separated by rip channels. The horizontal shape of the islands will thus largely be influenced by refracting surf waves. Therefore the flanks of elongated islands are often seen with landward directed 'horns', whereas round or ellipsoidal bar islands may develop one or two protuberances on the central part of the leeside; the latter was characteristic for the here investigated nearshore bar.

The nearshore bar does not change in form if exposed during low-water conditions if the water only falls continuously and at a certain speed. If the water-level stabilizes at a low level and cuts the leeside of the bar or the nearshore terrace farther seaward and the waves are moderate to swell-like, a swash bar will be built up in a few hours. With increasing water, the swash bar disappears as a form.

The migration direction is primarily governed by the incidence direction of the waves. When this is different from normal to the coast, the nearshore bar migration will furthermore be influenced by the wave-generated current's ability to transport suspended material parellel with the bar front and deposit it at sheltered places.

As the advance of the bar depends on material removed from stoss to leeside, the nearshore bar will follow the direction of the waves and consequently always be directed onshore. Nearshore bars migrating seaward, however, have also been observed by Davidsson 1963: 114-115, and Davis \& Fox 1972: 411. A possible explanation for Davidsson's observation might be that the migration pattern was determined on the basis of a single profile. A convex bar, advancing obliquely onshore, passing the profile line, might be misinterpretated as moving offshore, especially when the flanks are passing. An apparent movement away from the coast might also occur, if there is a conspicuous erosion on the leeside and/or on the flanks by a wave-generated current combined with rip channel dynamics, cf. fig. 13b. This, however, will induce a reduction of the sediments of the nearshore bar and not a dislocation away from the coast of the original băr.

\section{Material budget and development of volume}

On the basis of many observation points and the frequent measurements, it has been possible to calculate and construct a curve showing the total volume variations of the area by means of EDP (fig. 16). The volume can be calculated as the sum of the vertical prisms whose bases are determined by the grid net (reference plane: $-1 \mathrm{~m}$ DNN) and whose surface (level and gradient) is given by 3 measured levels. In order to analyse different parts of the study area we calculated, in the same profile lines as chosen for the T-D diagrams, the material budget in cubic metres gross and net for 24 hours in a belt of 1 metre along the line (fig. 17).

The material budget in connection with the migration of the nearshore bar balances as to changes in negative and positive volumes; net result is consequently zero. At no time during the process is this an obvious trend; on the contrary, the morphologically active periods can be divided into markedly destructive and constructive pha- 


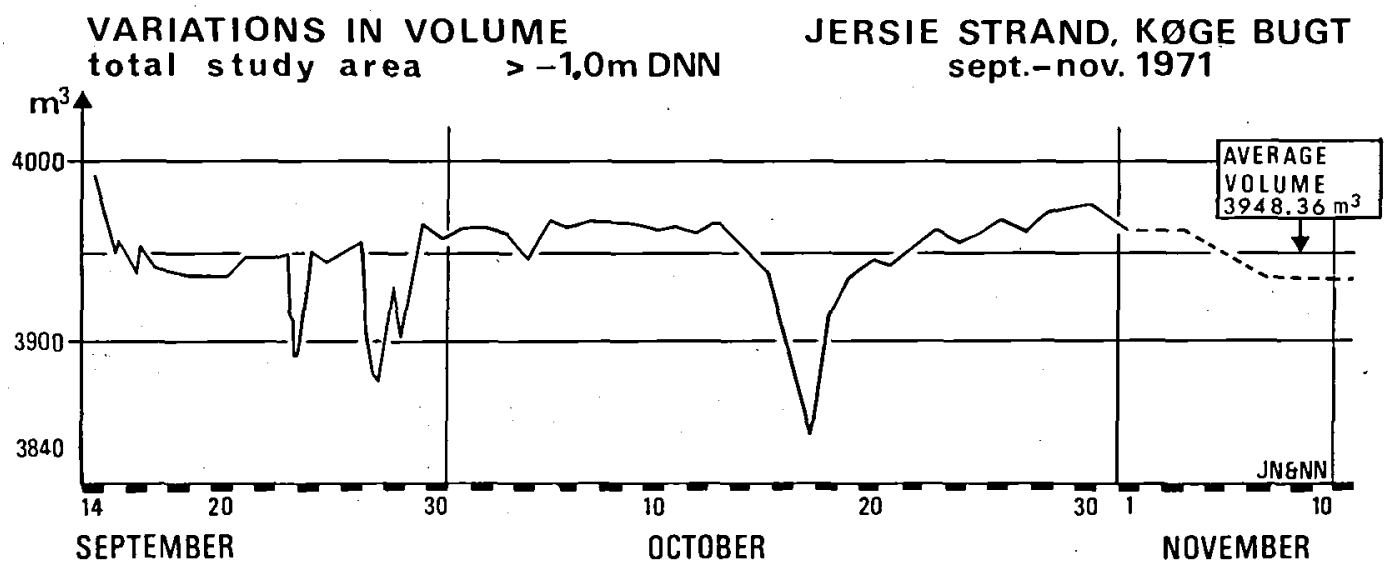

Fig. 16. Volume variations for the total analysed area. $-1 \mathrm{~m}$ DNN has been used as reference plane. The three sharply marked minima on the curve (net erosion for the whole area) are closely connected with the gale periods 23/9, 27/9, and $15-16 / 10$. Notice also that the total quantity is larger after a gale than before. ses, clearly mirrorred in the size of the net volume. This might be due to the oblique migration direction of the bar on the coast (fig. 12), and thereby on the orientation of the profile lines: from fig. 16, however, it is seen that there is a great loss of material in the total study area during the destructive phase of the active periods. Therefore the net values found must contain other factors than those originating solely from the migration of the nearshore bar. We may therefore presume that there is a general profile adjustment working on the nearshore terrace; during this, material is removed from the area and taken farther seaward, resulting in a flattening of the profile. Thus we are dealing here with two different components in this material budget: (1) one connected with the migrating nearshore bar;..(2) one connected with profile adjustments.

To test this hypothesis, the levels of the different profile sections were investigated (fig. 18). In each measuring point all changes in level were given a volume $(4 \times 1 \mathrm{~m} \times$ level change $)$ and a sign ( - for erosion, + for accumulation). The resulting histogram shows 3 areas with especially great variations: (1) the foreshore (profile adjustments); (2) the nearshore terrace (migrating bars); (3) the shoreface (profile adjustments).

- Simultaneously, highest and lowest level in each measuring point during the investigation period have been plotted. This shows the belt where the variations in profile occur, namely the sweep zone of the coastal profile. A comparison between the width of the sweep zone and the gross budget in the histogram indicates the frequency of the changes in level. Frequent, but small changes are to be expected in connection with profile adjustments, and few but great variations in connection with migrating bars.

The hypothesis that we are dealing with profile adjustments on foreshore and shoreface is further supported by the fact that the isolines in the T-D diagrams resume their original positions after the active periods.

Line 4, fig. 18 , shows a smaller gross budget that the other lines, but is more uniformly directed. Line 4 represents the lines off the nearshore bars and is therefore without the migrating bar's contribution (same size plus and minus contribution).

Fig. 16 shows clearly that there is no permanent loss of sediments during the active periods. On the contrary, there is a clear trend that the final volume is larger that the initial volume, as e.g. seen on $28 / 9$. This amazing phenomenon is due to the rebedding of material during the destructive phase in connection with the migration of the bar; this implies a net transport onshore from the outer part of the nearshore terrace and a profile adjustment with a net of transport offshore away from the shoreface. For a rebuilding of the normal profile during the constructive phase large amounts of material are needed to 

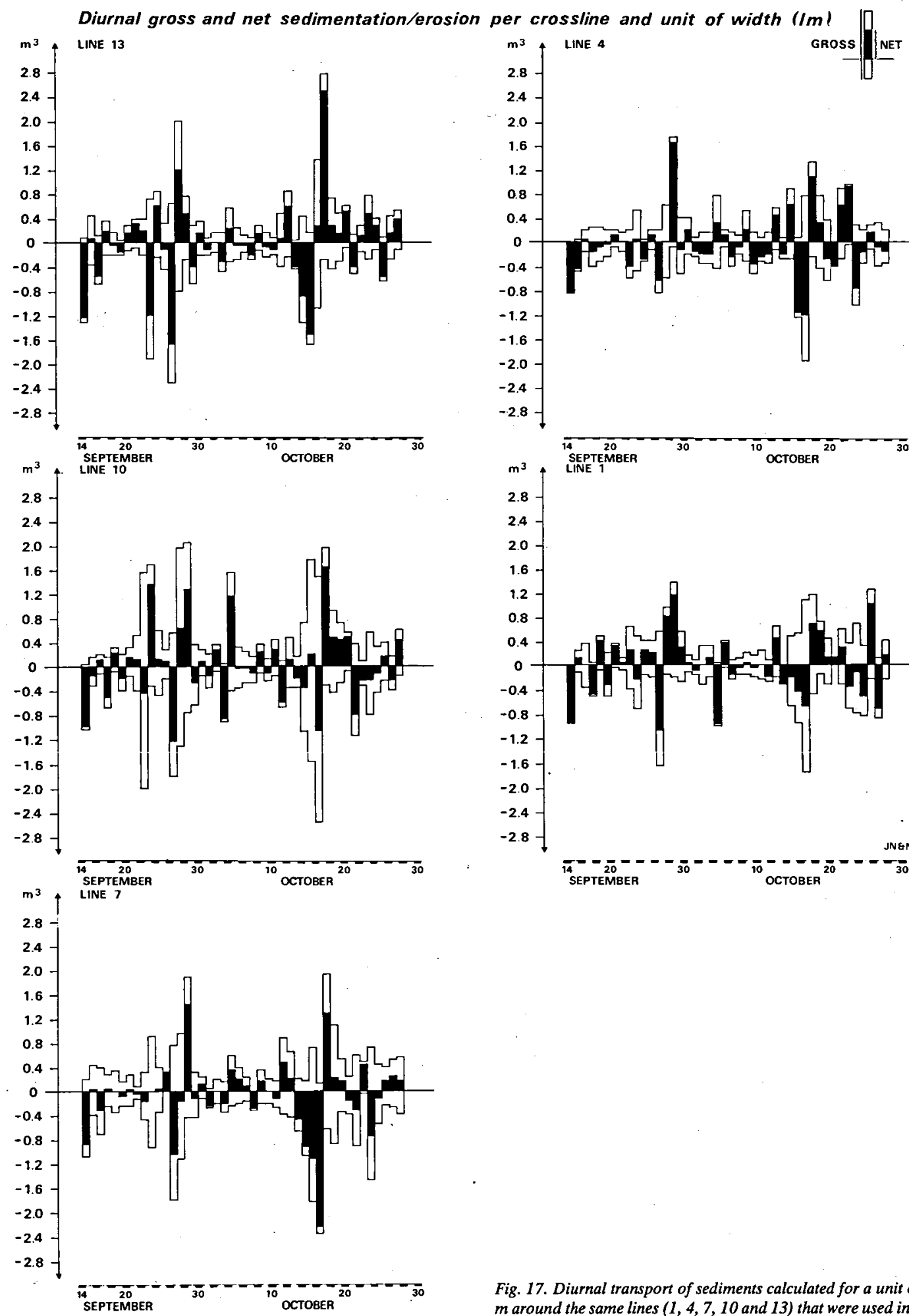

Fig. 17. Diurnal transport of sediments calculated for a unit of 1 $m$ around the same lines $(1,4,7,10$ and 13) that were used in the $T-D$ diagrams. For days with several measurements, only one measurement was used for the diagram. 

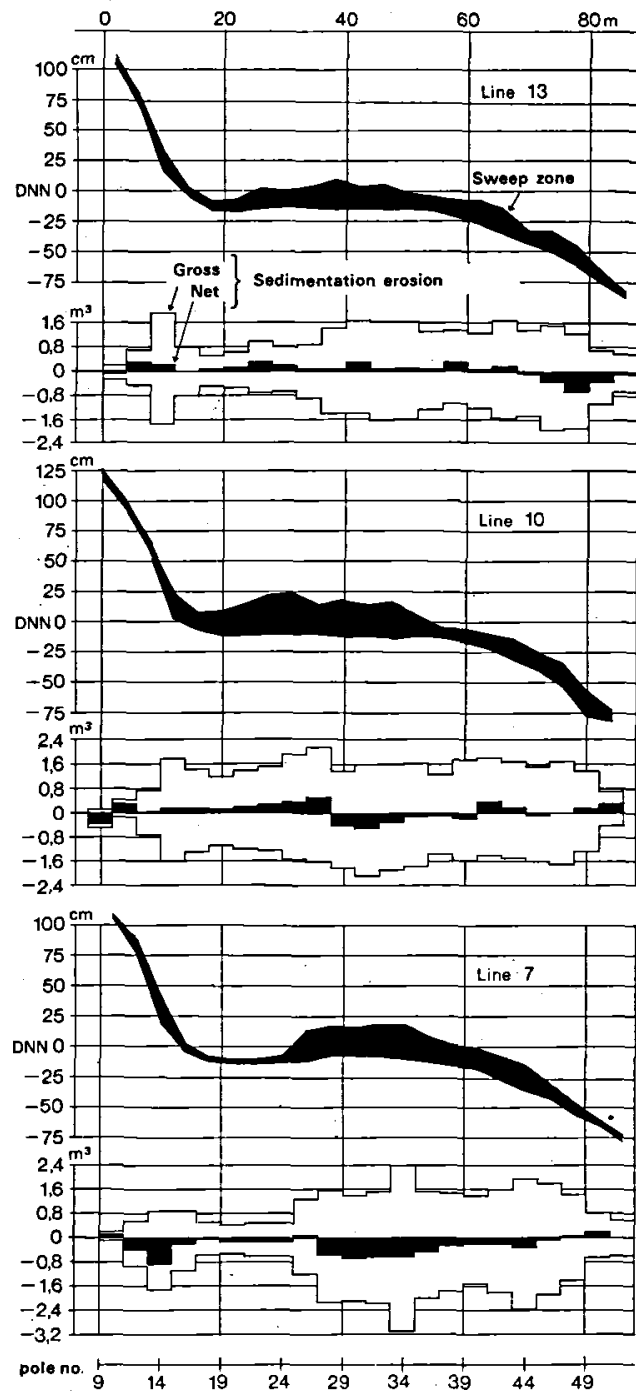

Fig. 18. The sweep zone of the coastal profile and the material transport around the observation points $(4 \times 1 \mathrm{~m})$ in the selected lines $(1,4,7,10$ and 13). All records for each line are included in

compensate both for losses produced by the migration of the bar and by profile adjustments. As the migration does not change the volume of the study area, the result will be a surplus of sediments after each active period. Sudden vigorous forces (such as onshore gales) have traditionally been ascribed great importance as to coastal morphological changes, morphological 'leaps' after a long period of stability. For the coast type in question the present investigation suggests that these catastrophy theories are not valid for the
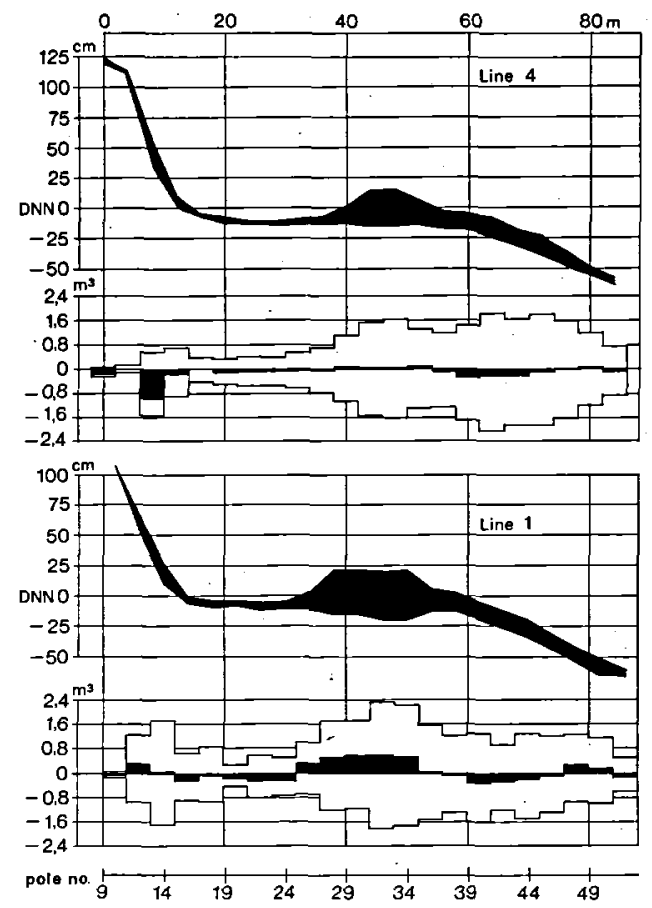

the diagrams. The white columns in the histograms indicate the gross sediment budget, the black columns the net budget.

sea-covered part of the coastal zone - the nearshore terrace.

\section{Erosion/sedimentation velocity}

In order to investigate the relation between processes and budget, the active period from $23 / 9$ to 29/9 was analyzed in greater detail (fig. 19). Until $23 / 9$ at 1100 rising water-level and an increasingly vigorous onshore wind were recorded. 


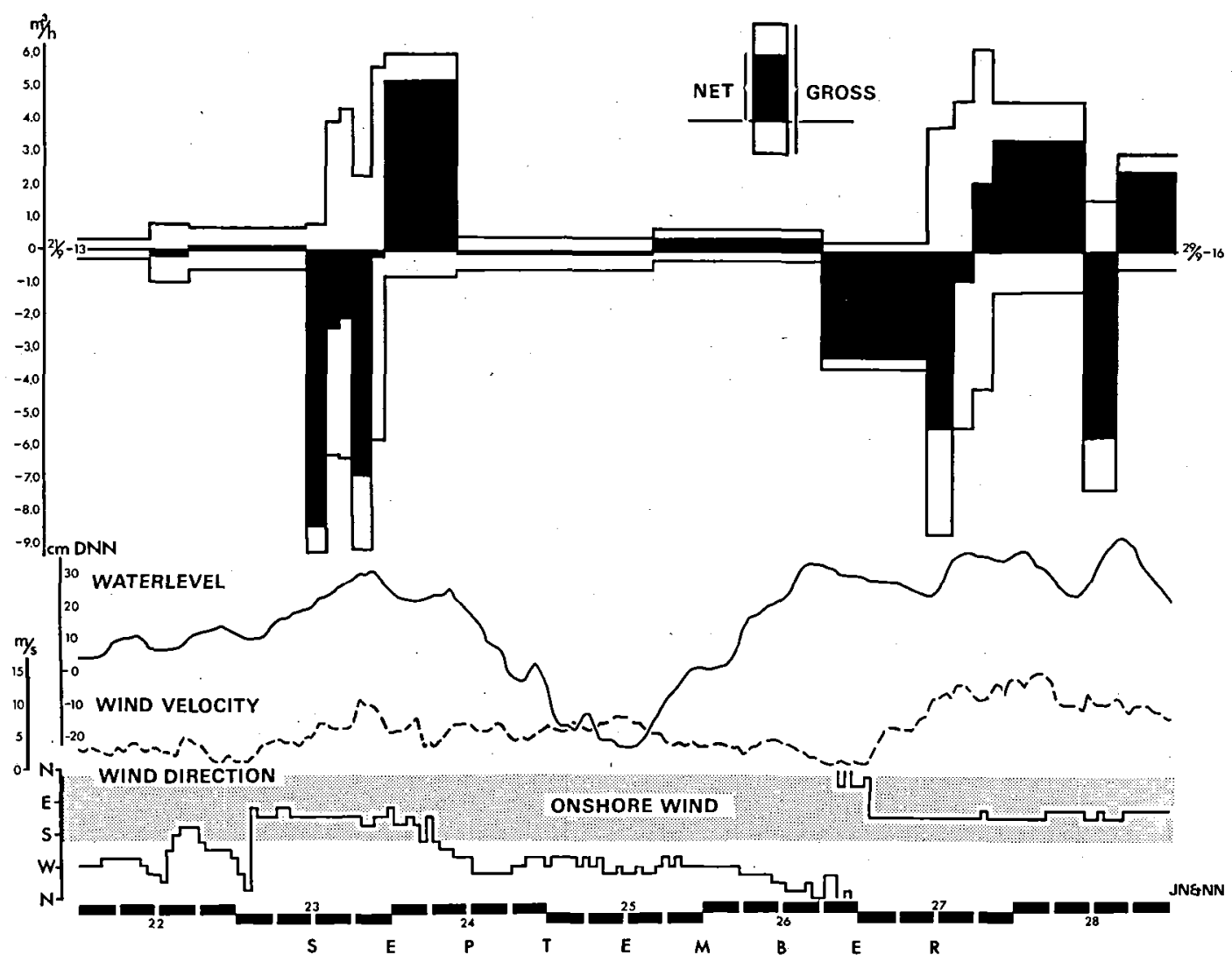

Fig. 19. The resedimentation velocity in $m^{3 / h}$ (this unit was chosen to give an area-true picture) between two subsequent measurements in the total investigation area with corresponding water-level curves, wind speeds and-direction for the period 22/9-28/9-1971 (as to wave parametres, cf. tables 1 and 2).

taking place at the highest speed, cf. fig. 12 and table 1.

Until 2030 the wind speed increases vigorously and the water-level is still slightly increasing. The changes, in the wave parametres involve a much more destructive profile adjustment whereas the material budget of the migrating bar simultaneously decreases.

Between 2030 and 2300 both water-level and wind speed decrease. The profile adjustment has therefore ceased, and the migration of the bar predominates. This can be considered a transition to 1030 on $24 / 9$ with offshore wind and decreasing water-level (at the time of measurement the bar is dry). A conspicuously constructive adjustment of the profile has taken place, whereas the bar has only migrated slightly. Notice that more material has been added than removed during the destructive period (fig. 16). The low 
water-level and the offshore wind result in a minimum of morphological activity during the 24 hours around 25/9.

At $184026 / 9$ the water-level is increasing, but there is still offshore wind (swell situation); as expected, the morphological activity is a weak, constructive adjustment of the profile.

During the night of 27/9 the wind turns from N to $\mathrm{E}$ (onshore wind) and simultaneously the wind speed increases markedly - the water-level decreases slightly. At 1000 a markedly destructive profile development is recorded and an insignificant transport in connection with the migrating bar. It deserves notice that the migration is slow at the beginning of the active periods, see also $23 / 9$ at 1400 .

Between 1000 and 1300 this development continues in consequence of increasing wind speed and water-level; the migration of the bar starts, however, and is relatively significant at the time of measurement. At 1700 the adjustments of the profile are accomplished, as both wind speed and water-level have remained constant, but the material budget in connection with the migration of the bar is almost the same. Until 1900 the water-level is constantly, but slightly decreasing, whereas the wind speed has slowed down. The magnitude of migration is largely unchanged, but a constructive profile development has started. This situation continues over night until 1000 $28 / 9$, although with decreasing migration velocity. Again a repetition is observed on the development around the active period 23/9; the migration of the bar is at a minimum during the constructive period.

Between 1000 and 1400 the water-level rises significantly, whereas the wind speed is constant. This results in an increased destructive adjustment of the profile, which was apparently at its maximum at the time of measurement.

Until next measurement at $160029 / 9$ both water-level and wind velocity decrease, and the final constructive development of the profile is accomplished (fig. 16).

On the basis of the detailed observations it can be concluded that the material transport in the investigation area must mainly be explained as profile adjustments. The frequent measurements reveal that they occur continuously and very rapidly. It is therefore important to stress that variations both in wind speeds, -directions and in water-levels are of great importance; fluctuations in these parametres, both isolated and together, induce a great morphological activity and a subsequent material transport.

It must therefore be stressed that each measurement only represents the morphological development during the last few hours and that the calculated gross budgets will generally be too small when the intervals between measurements surpass a few hours. It is interesting to notice that the migration of the nearshore bar is apparently at a minimum when there is a very active adjustment of the profile.

The main purpose of the volume calculations was to investigate whether the final phase of the migrating nearshore bar, when it is joining the foreshore, means a permanent contribution of material to the beach. Of the observed two nearshore bars, the first one did not quite reach fusion with the foreshore because another nearshore bar was formed farther seaward, and at the termination of the investigation the new bar had joined the first one (fig. 9j). If the migration of the nearshore bar results in a supplement of material, this should be seen in fig. 16 from around $1 / 11$; just at this time there is also a volume maximum. From a morphological viewpoint the foreshore is only contributing to this accumulation of material on a small scale which - as later measurements showed - was not permanent. The development during the last part of the investigation (after $1 / 11$ daily measurements were not taken) was a decrease in volume which was not obviously due to the dynamic conditions.

A comparison between the two contour maps from $14 / 9$ and $11 / 11$ (figs $9 \mathrm{a}$ and $9 \mathrm{j}$ ) reveals that during the observation period, the forms on the inshore terrace were dislocated northwards. It was thus to be expected that cyclically determined volume variations with low values were to occur just when the measurements were terminated.

With regard to the total material budget for the study period, table 3 , it must be emphasized that the indicated (measured) gross value must be too small because of the great intervals between the measurements; furthermore, that starting and final dates were chosen at random which has greatly influenced the net result. In spite of this, it is possible to get a picture of the magnitude of material transport in the area and especially of 
Table 3. Material budget for the total investigation period, 14/9-11/11 1971 .

\begin{tabular}{|c|c|c|c|c|c|c|}
\hline & & positive $\mathrm{m}^{3}$ & negative $\mathrm{m}^{3}$ & gross $\mathrm{m}^{3}$ & net $\mathrm{m}^{3}$ & net/gross \% \\
\hline Total area & . & 1080.2 & 1137.5 & 2217.7 & -57.3 & 2.6 \\
\hline Line 13 & $\mathbf{N}$ & 24.9 & 24.2 & 49.1 & +0.7 & 1.4 \\
\hline Line 10 & 极 & 30.6 & 28.9 & 59.5 & +1.7 & 2.9 \\
\hline Line 7 & & 25.2 & 30.9 & 56.1 & -5.7 & 10.2 \\
\hline Line 4 & $\downarrow$ & 21.1 & 24.0 & 45.1 & -2.9 & 6.4 \\
\hline Line 1 & $\dot{S}$ & 25.2 & 24.0 & 49.2 & +1.2 & 2.4 \\
\hline
\end{tabular}

the relationship between net and gross values. The net values for the single lines mirror the fact that the forms have migrated northward, notice especially line 7 . The very different results of the lines, placed at only $12 \mathrm{~m}$ intervals, emphasize the dubious value of the morphological and sedimentological studies on the basis of one or a few profile lines only.

In conclusion, the volume development must be understood as the sum of profile adjustments during the active periods, and the component parallel to the coast of the nearshore bar's migration. At the termination of the investigations it could not be stated unambiguously whether the migration of the bar permanently yields material to the beach.

\section{Effect of an extreme weather situation}

The investigation was terminated on 11/11-1971. About two weeks later a cyclone passed Denmark. The night between 21 and 22/11 the wind turned ESE and increased to above $20 \mathrm{~m} / \mathrm{sec}$. Simultaneously the water-level rose from $+20 \mathrm{~cm}$ DNN to a maximum of +124 $\mathrm{cm}, \mathrm{cf}$. the wind and water-level curves. The wave heights were not directly observed, but according to prognosis diagrams for coastal waters (Darbyshire \& Draper 1962, Petersen \& Poulsen 1975) the $H_{s}$ must have been $3-4 \mathrm{~m}$ on 'deep' water.

On 26/11 the study area was measured by tachymetry, (fig. 20) and the volume was calculated by planimetry.

The nearshore terrace shows a levelled morphology and the 'old' nearshore bars can be discerned in the northern part of the map by their higher level. A coast-parallel ridge has been built up c. $50 \mathrm{~m}$ out on the nearshore terrace and extends throughout the whole section. The ridge has probably been formed during the gale's high water-levels as an inner breakpoint bar, is therefore temporary and, on the day of measurement, under transformation into a nearshore bar.

A comparison between the morphology in the area on $26 / 11$ and $11 / 11$ indicates a significant retreat of the beach and a minor decrease in gradient (fig. 21).

In spite of a marked erosion on the beach, the volume (>-1 m DNN) in the proper study area showed a higher value than the average volume and the volumes for the active periods in September and October (fig. 16).

The volume of the study area $(>-1 \mathrm{~m}$ DNN):

$\begin{array}{ll}\text { Average } & 3948 \mathrm{~m}^{3} \\ \text { on } 29 / 9 & 3965 \mathrm{~m}^{3} \\ \text { on } 31 / 10 & 3977 \mathrm{~m}^{3} \\ \text { on } 11 / 11 & 3924 \mathrm{~m}^{3} \\ \text { on } 26 / 11 & 3978 \mathrm{~m}^{3}\end{array}$

On 21-22/11 the swash transported material over the outermost barrier top (fig. 22) and thus definitely away from the area. A volume calculation for the landward continuation of the study area showed a sediment increase of $32.1 \mathrm{~m}^{3}$.

It is therefore interesting to notice that in spite of a marked erosion on the fore- and backshore the whole barrier unit (barrier, beach and nearshore), showed an increased sediment volume after the gale. It cannot be said whether a gale like this will always have a 'sediment accumulating' effect, because we only have this single event. But it is justified to conclude that the profile adjustment immediately after the gale on $22 / 11$ benefitted from sediment seaward of the study area. In future investigations it will therefore be essential to include the area in front of the nearshore face. 
Bulletin of the Geological Society of Denmark, vol. 271978

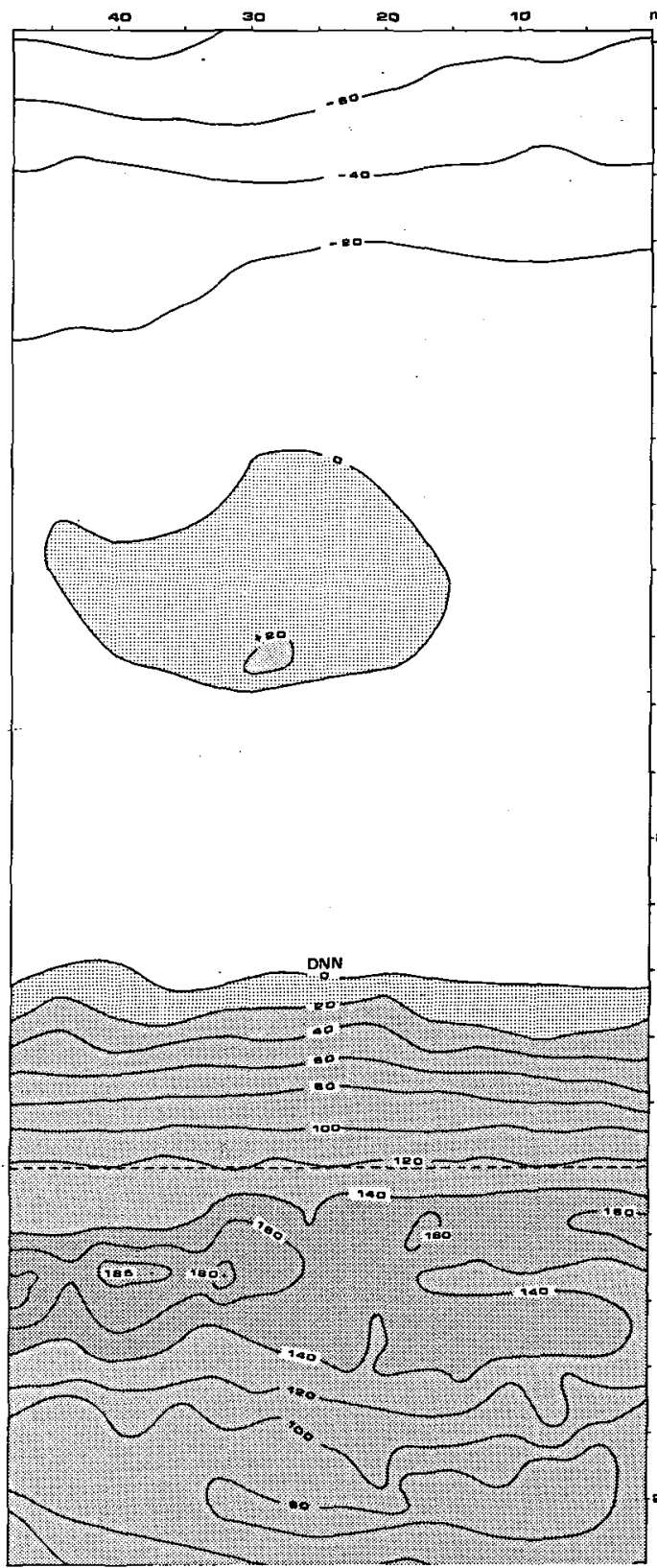

a SEPT. 16. 1971
30

2o

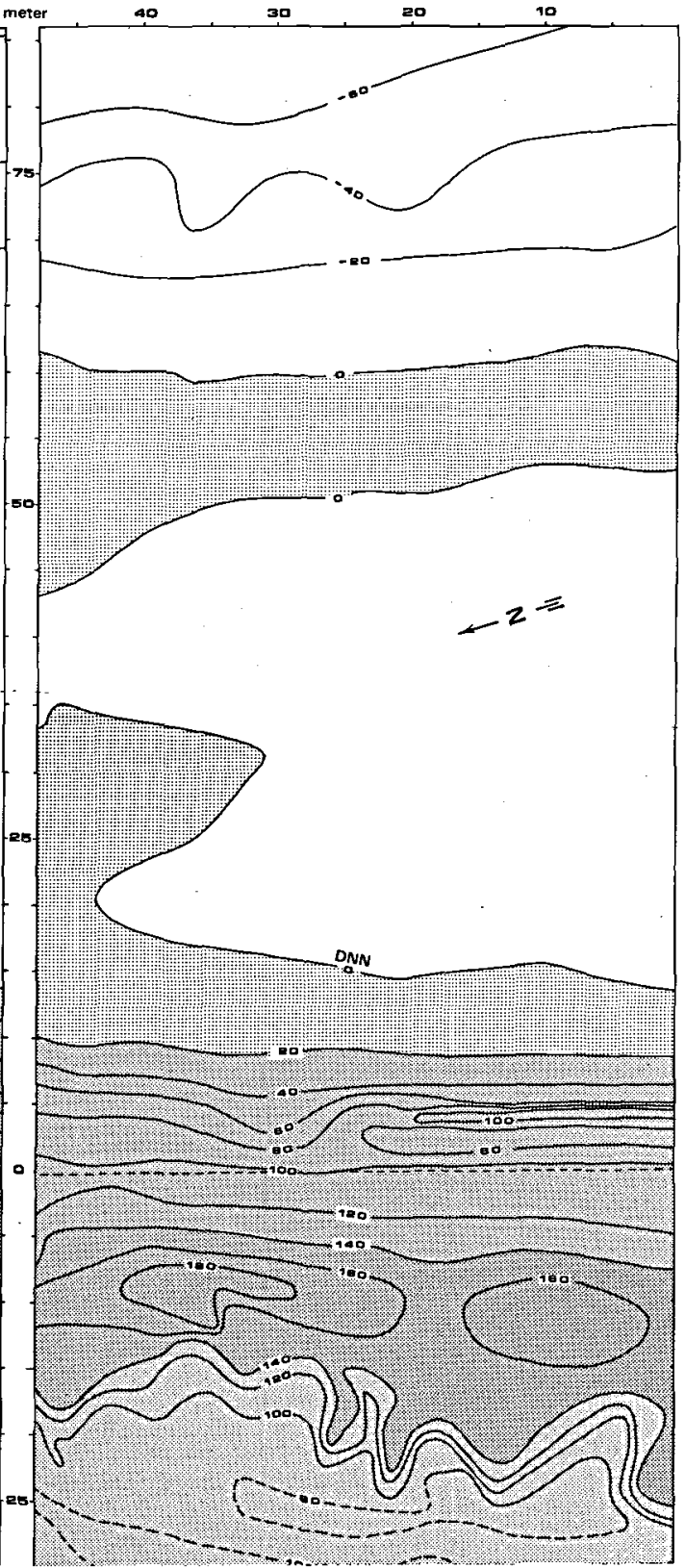

Nov. 26. 1971 b

Fig. 20. The investigation area and part of the bar surveyed on 16/9 and 26/11-1971 (tachymetric surveying). The contour picture landward of the 0 DNN $16 / 9$ was stable until the gale $22 / 11$. For $26 / 11$, on the backside of the outermost barrier ridge,

the contour picture shows swash tongues which are thus participating in a strengthening of the barrier. The dashed line on the backshore c. $100-120 \mathrm{~cm}$ DNN shows the inner limit of the data maps. 


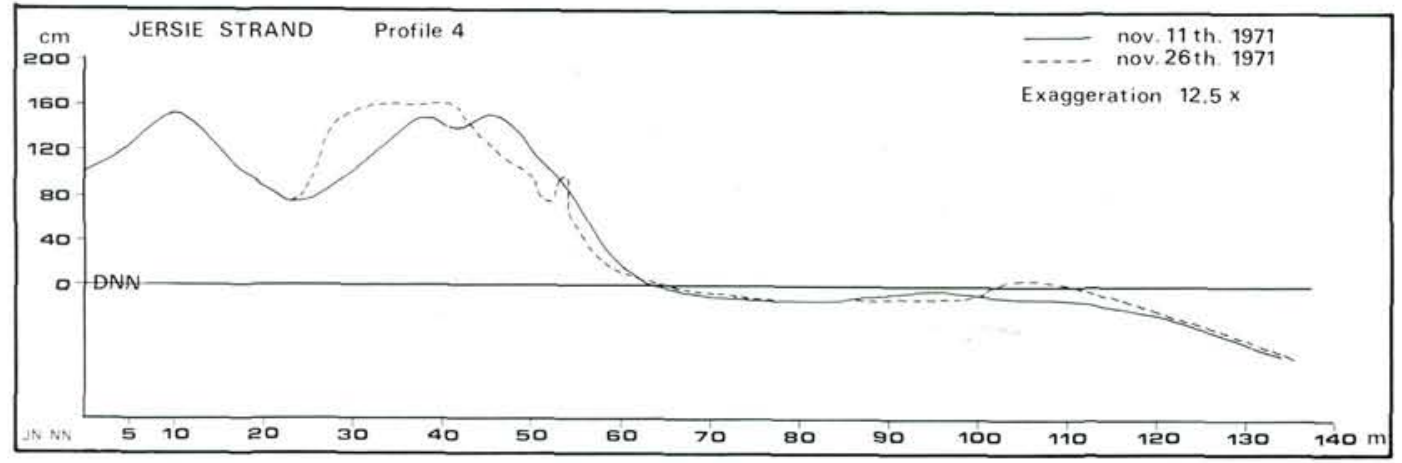

Fig. 21. Cross profile of line 4 measured on $11 / 11$ and $26 / 11$ i.e. before and after the gale 22/11. The nearshore terrace is apparently not influenced by the gale except in the transition into the nearshore face where a secondary breakpoint bar has been formed. Surveying was not made during the gale, but by analogy

\section{Concluding remarks}

The method described here was chosen in an attempt to benefit from the advantages of a model study and obtain unambiguous and precise point observations, to register short-interval variations and thus avoid the unfortunate and often unforeseeable distortion of scale that basin studies might involve. What it meant in extra time when establishing the measurement net was regained with earlier records, considerable erosion must have taken place on the nearshore terrace, which has been rebuilt now 3 days after the gale. Notice the large accumulations of material behind the outermost ridge of the barrier.

during the routine measurements which were thereby secured a high degree of accuracy. In our opinion the most valuable observations in this investigation were obtained thanks to the permanent grid net which enabled us to take records at short intervals during dynamically very active periods and at any time of the day.

The primary goal was to obtain a better knowledge of the relationship: process/form/change of form; choice of measuring period was therefore of minor importance. It should be added, how-

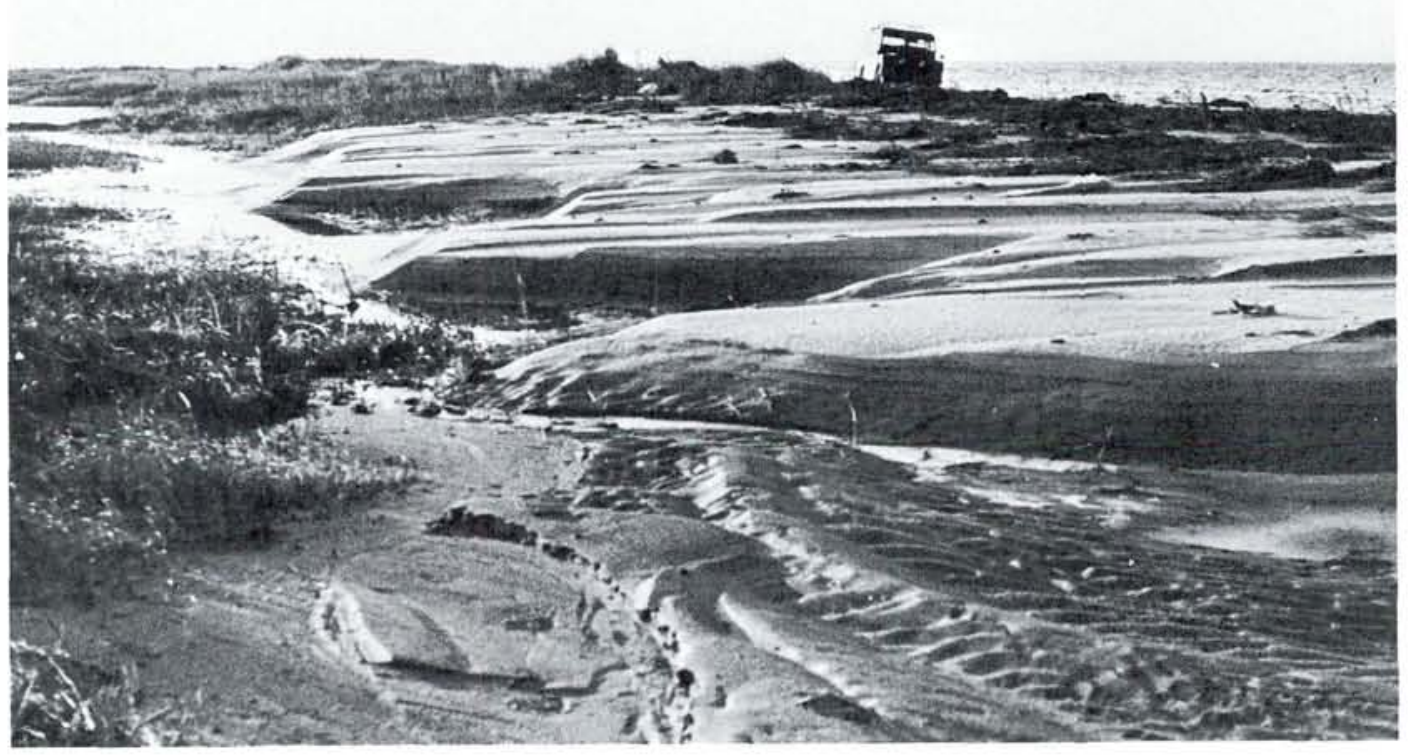

Fig. 22. Swash tongues on the backside of the outermost bar ridge, formed after the gale 22/11-1971. 
ever, that in September-November 1971 the weather conditions were normal for the season with the exception of the gale on 22/11.

Considering the advantages of the described method, it would be of great interest to continue with similar studies, based upon two different criteria: (1) A repetition of the whole measuring procedure for a 1-2 month period on coasts differently exposed and consequently having different wave and water-level parametres. (2) To prolong the measurements to a minimum of one year to investigate the seasonally determined variations in budgets and forms.

Acknowledgements. The processing of the large amount of data was made possible thanks to Ole Hebin's great interest and understanding of the problem complex. The authors also wish to extend their thanks to Prof. Harald Svensson who kindly read the manuscript critically, to Kirsten Winther who translated it into English, and to John Jensson who made the final drawing work.

\section{Dansk sammendrag}

Undersøgelsen ved Jersie Strand, Køge Bugt belyser nogle af de formmæssige variationer, der finder sted $i$ den littorale zone, primært på strandplansterrassen og på strandplansskråningen. Kysten er på denne lokalitet opbygget af mellem- til finsandede sedimenter, og tidevandet er som procesparameter uden betydring.

Studierne blev koncentreret til forholdene omkring morfologiens geometri og til materialeomsætningen. Analysegrundlaget består af 65 detaljerede topografiske opmålinger. Konstruktionen af de 65 kort (areal $48 \times 86 \mathrm{~m}$, med $5 \mathrm{~cm}$ kurveinterval) er baseret på dataindsamlinger $i$ et fast markeret, tilnærmet isometrisk net. 1 tidsserieanalysen, der dækker en periode på 2 måneder, indgår desuden kontinuerligt registrerede vind-, vand- og bolgedata. Korttegning og volumenberegninger er foretaget med EDB.

De vigtigste morfologiske ændringer på strandplansterrassen er snævert forbundet med strandrevlens vakst og vandring. Undersøgelsen viste, at strandrevlen kunne opstå såvel ved høj som ved lav vandstand, dels $i$ form af en initial brandingsrevle og dels som en opskylsryg. Strandrevlens vandringsretning var altid rettet mod kysten. Den eneste forudsætning for bevægelse var vanddækning eller blot bølgeoverskyl. Der observeredes invandringshastigheder på op til $30 \mathrm{~cm} /$ time i perioder med pålandsvind og under konstante vandstandsforhold og/eller konstant vindhastighed.

Ud fra en analyse af materialets brutto/nettoomlejring kunne der klart skelnes mellem strandrevlens formvandringer og profiljusteringernes materiale-input/output i forsøgsarealet. Særlig bemærkelsesværdig var, at sedimenttilførslen efter en storm var større end den sedimentmasse, der blev fjernet fra arealet under stormen. Endvidere kunne det vises, at strandplanets og strandbreddens (barrierens) samlede materialemængde stort set var konstant (i forsøgsarealet), trods markante forminvandringer $i$ undersøgelsesperioden. Kun en ekstraordinær stormsituation i slutningen af observationsfasen tilførte barrieren materiale af blivende karakter.

\section{References}

Chole, J. \& van Beek, J. L. 1971: Systematic Beach Changes on the Outer Banks, North Carolina. J. Geol. 79:416-425.

Darbyshire, M. \& Draper, L. 1963: Forecasting wind-generated sea Waves. Engineering 195: 482-484.

Davidsson, J. 1963: Littoral Processes and Morphology on . Scanian Flat-Coasts. Lund Studies in Geography. Physical Geography (A) 23: 232 pp.

Davis, R. A., Fox, W. T., Hayes, M. O. \& Boothroyd, J. C. 1972: Comparison of Ridge and Runnel Systems in Tidal and Non-Tidal Environments. J. sed. Petrol. 42: 413-421.

Davis, R. A. \& Fox, W. T. 1972: Four-dimensional Model for Beach and Inner Nearshore Sedimentation. J. Geol. 80: 484-493.

Davis, R. A. \& Fox, W. T. 1972: Coastal Processes and Nearshore Sand-Bars. J. sed Petrol. 42: 413-421.

Folk, R. L. \& Ward, C. W. 1957: Brazos River Bar: A Study in the Significanse of Grain Size parameters. J. sed. Petrol. 27: 3-27.

Hayes, M. O. \& Boothroyd, J. C. 1969: Storms as modifying agents in the coastal environment. In: M. O. Hayes (ed.): Coastal environment: NE Massachusetts, 290-315. Dept. of Geology, Univ. of Mass., Amherst.

Hayes, M. O. 1972: Forms of sediment accumulation in the beach zone. In: R. E. Meyer (ed.): Waves on beaches, 297-356. New York: Academic Press.

Isotopcentralen 1962, 1963, and 1965: (Unpubl.) Recipientundersøgelse, Køge Bugt.

King, C. A. M. 1972: Beaches and coasts. 570 pp. 2 nd ed. New York: St. Martin's Press.

King, C. A. M. \& Williams, W. W. 1949: The Formation and Movement of Sand Bars by Waves. Geogr. J. 113: 70-85.

Nielsen, J. \& Nielsen, N. 1974: Kystmorfologi. Geo-Noter, særhæfte Nr. $1.156 \mathrm{pp}$.

Petersen, K. D. \& Poulsen, S. 1975: Overfladesedimenter på Juels Grund, Køge Flak. Geo-Noter, særhæfte Nr. 3. 116 pp.

Schou, A. 1945: Det marine Forland. Folia Geogr. Danica 4: $236 \mathrm{pp}$. 